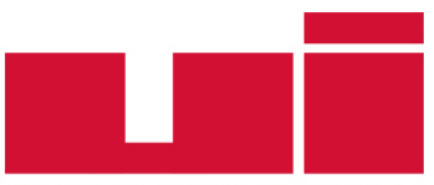

ULUUSLARARASIILIŞKiLER

Akademik Dergi

Yayın ilkeleri, izinler ve abonelik hakkında ayrıntılı bilgi:

E-mail: bilgi@uidergisi.com.tr

Web: www.uidergisi.com.tr

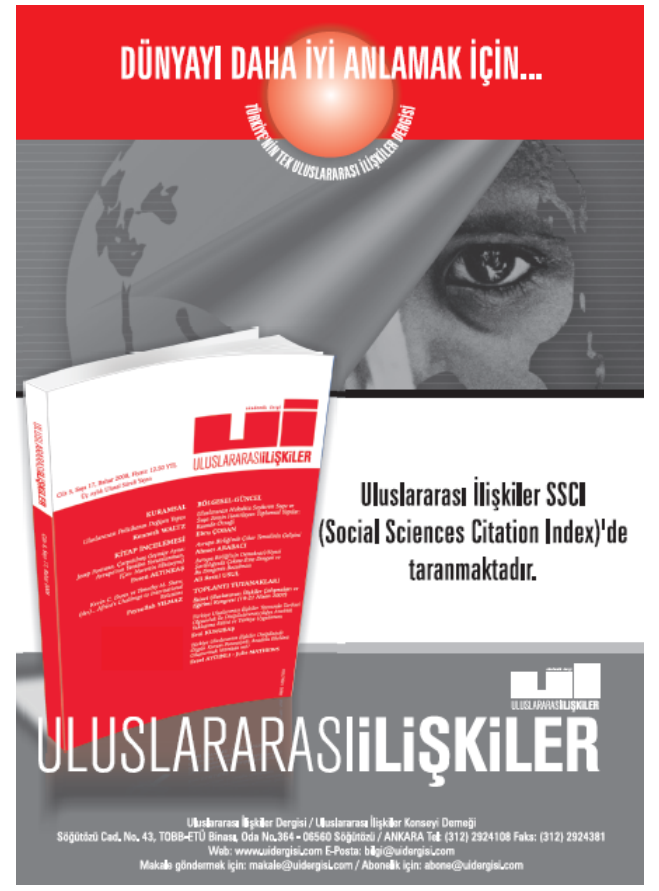

\title{
Emperyalizm Karşıtlığı ve Kemalizm: Tek- Parti Döneminde "Europacentrisme'in Tasfiyesi” ve "İktibascı Ínkılâb” Tartışmaları
}

\author{
Ömer TURAN* \\ * Yrd. Doç. Dr., İstanbul Bilgi Üniversitesi, Uluslararası \\ İlişkiler Bölümü
}

Bu makaleye atıf için: Turan, Ömer, "Emperyalizm Karşıtlı̆̆ ve Kemalizm: Tek-Parti Döneminde "Europacentrisme'in Tasfiyesi" ve "İktibascı İnkılâb" Tartışmaları", Uluslararası İlişkiler, Cilt 11, Say1 43 (Güz 2014), s. 81-104.

Bu makalenin tüm hakları Uluslararası İlişkiler Konseyi Derneği’ne aittir. Önceden yazılı izin alınmadan hiç bir iletişim, kopyalama ya da yayın sistemi kullanılarak yeniden yayımlanamaz, çoğaltılamaz, dağıtılamaz, satılamaz veya herhangi bir şekilde kamunun ücretli/ücretsiz kullanımına sunulamaz. Akademik ve haber amaçlı kısa alıntılar bu kuralın dışındadır.

Aksi belirtilmediği sürece Uluslararası Illişkiler'de yayınlanan yazılarda belirtilen fikirler yalnızca yazarına/yazarlarına aittir. UIKK Derneğini, editörleri ve diğer yazarları bağlamaz. 


\title{
Emperyalizm Karşıtlı̆ğ ve Kemalizm: Tek-Parti Döneminde "Europacentrisme'in Tasfiyesi” ve "İktibasçı İnkılâb” Tartışmaları
}

\author{
Ömer TURAN*
}

\section{ÖZET}

Tek-parti döneminin düşünce tarihi, dönemin fikir ayrılıklarını ele alırken, genel olarak iktisat politikaları tartışmalarına odaklanmıştır. Bu makale ise şu ana kadar üzerinde çok durulmamış bir fikir ayrılığına odaklanmayı hedefliyor. Celâl Nuri’nin Türk İnkılâbı kitabını (1926) ve Şevket Süreyya’nın Kadro yazılarını tartışarak, Kemalist entelektüeller arasındaki farklı modernleşme tahayyüllerini değerlendiriyor. 1920'ler ve 1930'lar boyunca, Kemalist entelektüeller bir dizi kuramsal sorunla karşı karşıya kalmışlardı. Bu sorunların başlıcası Batı dışı bir toplumda modernleşmenin hangi temeller üzerine inşa edileceğiydi. Bu makale koşulsuz Batılılaşmadan yana tavır koyan Celâl Nuri ile ve özgün modernleşme projesinin gereğini savunan Şevket Süreyyànın yazdıklarına odaklanarak Kemalizm içi bu tartışmayı incelemeyi hedeflemektedir.

Anahtar Kelimeler: Celâl Nuri (İleri), Şevket Süreyya (Aydemir), Emperyalizm, Avrupamerkezcilik, Küresel Hiyerarşiler.

\section{Anti-Imperialism and Kemalism: Discussions on "Liquidation of Europacentrisme" and Adaptive Reformism in the Single Party Era}

\begin{abstract}
The intellectual history of the single-party era has been mostly studied by focusing on debates over economic policies. This article focuses on an under-studied debate. By analyzing Celâl Nuri's Turkish Revolution (1926) and Şevket Süreyya's Kadro articles, it discusses different imaginations of modernity conceived by different Kemalist intellectuals. Throughout the 1920s and 1930s, Kemalist intellectuals encountered a series of theoretical questions. The basic question was about the basis of modernization project in a non-Western society. By revisiting Celâl Nuri, who was in favor of an unconditional and comprehensive Westernization and Şevket Süreyya, who was in favor of an authentic modernization project, this article analyzes this intra-Kemalist debate.
\end{abstract}

Keywords: Celâl Nuri (İleri), Şevket Süreyya (Aydemir), Imperialism, Eurocentrism, Global Hierarchies.

* Yrd. Doç. Dr., Uluslararası İlişkiler Bölümü, İİBF, İstanbul Bilgi Üniversitesi. E-posta: omer.turan@bilgi.edu.tr. Bu makale, Central European University (Budapeşte), Sosyoloji ve Sosyal Antropoloji Bölümü'nde Temmuz 2012'de savunduğum "Facing Eurocentrism, Facing Modernity: Questions of Modernization and Global Hierarchies in Turkish Intellectual History” başlıklı doktora tezinin bir bölümüne dayanmaktadır. Çalışmanın bu hâli Şubat 2014'te, Tarih Vakfı tarafından düzenlenen "Ankara Tartışmaları" başlıklı seminer serisinde sunulmuştur. Farklı ortamlarda soru, görüş ve eleştirileriyle çalışmaya katkıda bulunanlara teşekkür ederim. 


\section{Giriş}

2010'lara gelindiğinde farklı disiplin ve perspektiflerden gelen katkılarla Türkiye'nin düşünce tarihine ilişkin kayda değer bir literatür oluşmuş durumda. Gerek tek bir entelektüele odaklanan monograflar, gerekse dönem, dergi ya da akımları inceleyen çalışmalar sayesinde son dönem Osmanlı İmparatorluğu'ndaki fikir akımlarını, İmparatorluktan Cumhuriyet'e geçişin fikir dünyasındaki yansımalarını ve Cumhuriyet boyunca farklı siyasal ve düşünsel pozisyonların arkaplanlarını detaylarıyla biliyoruz. Fakat entelektüel tarih literatürünün bu denli gelişmiş olmasına karşın, erken Cumhuriyet dönemine odaklanan çalı̧̧malarda genel bir eksiklik gözlenmekte. Bu eksiklik Kemalist entelektüeller arasındaki modernleşme tahayyüllerine ilişkin fikir ayrilıklarının görmezden gelinmesi ya da Kemalist modernleşme düşüncesinin homojen bir grubun projesi olarak değerlendirilmesi olarak özetlenebilir. Bu makale Celâl Nuri'nin Türk İnkılâbı kitabı (1926) ve Şevket Süreyya'nın Kadro yazıları üzerinden, Kemalizm içi farklı modernleşme formülasyonlarını tartışarak ve bu farklı formülasyonların emperyalizm analizleri ile ilişkilerini kurarak bu eksikliğin giderilmesine katkıda bulunmayı amaçlıyor. ${ }^{1}$ Erken Cumhuriyet dönemindeki farklı Kemalist modernleşme önerilerinin incelenmesi, son dönemde Türkiye'nin Avrupa Birliği ile uyum sürecine eşlik eden, Avrupa normlar çerçevesinin ne ölçüde benimsenmesi gerektiği, bu normlar benimsenirken özgünlüklerin ne ölçüde korunacağı ve farkl1llklar korunarak mı yoksa silinerek mi modernleşilmesi gerektiğine ilişkin tartı̧̧maların tarihsel arkaplanına yönelik bir çerçeve de sunuyor.

Tek-parti döneminin düşünce tarihine ilişkin literatür, dönemin entelektüelleri arasındaki fikir ayrılıklarını ve polemikleri ele alırken, genel olarak iktisat politikalarına ve devletçilik-liberalizm tartı̧̧malarına odaklanmıştır. Bu çerçevede örneğin Ağaoğlu Ahmed'in dönemin devletçilik uygulamalarına yönelik eleştirileri ve devletçi kanadın yazarları ile olan polemikleri detayları ile ele alınmıştır. ${ }^{2}$ Literatürde detayları ile ele alınan bir diğer fikir ayrillğı ise tek-parti dönemi muhafazakâr entelektüellerinin düşünsel kaynakları ve alternatif modernite arayışları ile kendilerini Kemalist modernleşme çizgisinden ayrı̧̧tırma çabalarıdır. ${ }^{3}$ Nasıl Ağaoğlu Ahmed ve diğer iktisadi devletçilik karşıtı ente-

1 Metin Çınar'ın kitabını aynı yönde atılmış daha kapsamlı bir adım olarak anmak gerekiyor; Metin Çınar, Anadoluculuk ve Tek Parti CHP'de Sağ Kanat, İstanbul, İletişim Yayınları, 2013.

2 İlhan Tekeli ve Selim İlkin, Uygulamaya Geçerken Türkiye'de Devletçiliğin Oluşumu, Ankara, Orta Doğu Teknik Üniversitesi, 1982. Ağaoğlu Ahmed'in Kadrocular ile polemiklerinin Kadro'nun her sayısı özelinde detaylı bir analizi için bkz. İlhan Tekeli ve Selim İlkin, Bir Cumburiyet Öyküsü: Kadrocuları ve Kadro'yu Anlamak, İstanbul, Tarih Vakfı Yurt Yayınları, 2003. Devletçilik-liberalizm tartışmaları literatürde sadece entelektüellere odaklanarak ele alınmamış, İnönü ile Bayar arasındaki gerilim, hatta Atatürk ile İnönü arasında gelişen ve zamanla içine dış politika konularındaki çatışmaları da alan fikir ayrılıkları da çözümlenmiştir. Bkz. Cemil Koçak, Türkiyéde Millî Şef Dönemi (1938-1945), Cilt 1, İstanbul, İletişim Yayınları, 1996.

3 Nazım İrem, “Muhafazakâr Modernlik, 'Diğer Batı' ve Türkiye'de Bergsonculuk”, Toplum ve Bilim, No.82,1999, s.141-179; Tanel Demirel, "Cumhuriyet Döneminde Alternatif Batılllaşma Arayışları: 1945 Sonrası Muhafazakâr Modernleşmeci Eğilimler Üzerine Bazı Değinmeler”, Uygur Kocabaşoğlu (der.), Modern Türkiye’de Siyasî Düşünce: Batıcılık, Cilt 3, İstanbul, İletişim Yayinlar1, 2002, s.218-238. 
lektüeller Kadro çevresi ile polemiğe girmişlerse Mustafa Şekip Tunç, Hilmi Ziya Ülken, Peyami Safa gibi cumhuriyetçi muhafazakârlar da Kadrocular ile polemiğe girişmişlerdir. ${ }^{4}$ Ve bu fikir ayrılıkları da ilgili literatürde yer bulmuştur.

Kemalizm içi fikir ayrılıklarının iktisadi konulardan ibaret sayılmasının ve Kemalizm içinde modernleşme konusundaki fikir ayrılıklarına yeterince değinilmemiş olmasının bir dizi nedeninden söz edilebilir. Nedenlerden biri literatürün fazlasıyla Atatürk merkezli olarak şekillenmiş olmasıdır. Bir diğer neden olarak, Kemalizm’in diğer coğrafi bağlamlarla karşılaştırmalı analizinin ve ilişkilerinin yeterince çalışılmamış olmasını vurgulamak gerekiyor. Karşılaştırmalı perspektif eksik kaldıkça, Batı dışı bir coğrafyada bir modernite projesi inşa etme girişimi olan Kemalizm’in karşı karşıya kaldığı kuramsal sorunlar da yeterince tartışılamıyor. Bu makalede izlenen çerçevenin iddiası, eski formel sömürge olan coğrafyaların modernite ile karşılaşmalarındaki kuramsal sorunların, formel anlamda sömürge olmamış fakat yine de Avrupa kapitalizminin genişlemesi tarafindan kontrol edilmiş coğrafyaların modernite deneyimlerinde karşılaştıkları sorunlarla belirgin ortak özelliklere sahip olduğu ve tartışmanın bu ortaklık vurgulanarak derinleştirilmesi gerektiğidir. Bu çerçevede önerilen, Türkiye'nin modernleşme deneyimini küresel hiyerarşiler bağlamında değerlendirmektir. Çünkü Batı dışı modernitelerde yerel modernite iddiasını dile getirmenin şartı, çoğu durumda Avrupa'nın üstünlük iddiasına karşı çıkmak ve eşitlik/tanınma arayışlarını dillendirmek olmuştur.

Küresel hiyerarşiler kavramının üç tanımlayıcı unsurunu vurgulamak gerekiyor. ${ }^{5}$ İlk olarak küresel hiyerarşiler küresel kapitalizmin yarattığı mekânsal işbölümüne dayanmaktadır. Bu anlamda her tür formel ve enformel sömürgecilik, himaye altındaki ülke, bağımlı ülke, dominyon, eşitsiz antlaşma sistemleri, donanmalarca desteklenen gözdağ1 siyasetleri ve zorla dayatılan imtiyazlar küresel hiyerarşilerin tezahürleri olarak belirmektedir. Küresel hiyerarşilerin ikinci dayanak noktası Batı'nın kültürel üstünlük iddialarıdır. Bu üstünlük iddialarına Batılı olmayanlara karşı her türlü ırkçı ve Oryantalist önyargılar da eşlik etmektedir. Elbette Avrupamerkezcilik de küresel hiyerarşilerin ayrılmaz bir parçasıdır. Üçüncü olarak, küresel hiyerarşiler tarihsel olarak bir takım gri bölgeler, alt-emperyalist sistemler aracılığ 1 ile işlev görürler. Bu anlamda bir coğrafya hem kontrol edilen hem de bir alt-sistem kapsamında kontrol eden olarak belirebilir ve dolayısıyla bir yandan kültürel önyargılara maruz kalırken, bir yandan da başka coğrafyalara yönelik önyargılar üretebilir.

Küresel hiyerarşiler bağlamında düşündüğümüzde 19. yüzyıldan 20. yüzyıla Batı dışı modernite deneyimlerinin bir dizi ortak özelliğini gözlemek mümkün. İlk olarak bu deneyimlere bir gecikmişlik algısı eşlik etmektedir. ${ }^{6}$ Bu gecikmişlik algısıyla birlikte, bir

4 Tekeli ve İlkin, Kadrocuları ve Kadro'yu Anlamak, s.321-323; Nazım İrem, "Bir Değişim Siyaseti Olarak Türkiye'de Cumhuriyetçi Muhafazakârlık: Temel Kavramlar Üzerine Bir Değerlendirme”, Ahmet Çiğdem (der.) Modern Türkiye’de Siyasî Düşünce: Mubafazakârlık, Cilt 5, İstanbul, İletişim Yayınları, 2003, s.105-117.

5 ÖmerTuran, "Oryantalizm, Sömürgecilik Eleştirisi ve Ahmed Rıza: Batı’nın Doğu Politikasının Ablâken İflasinı Yeniden Okumak”, Toplum ve Bilim, No.115, 2009, s.6-45.

6 Gregory Jusdanis, Gecikmiş Modernlik ve Estetik Kültür: Milli Edebiyatın İcat Edilişsi, İstanbul, Metis Yayınları, 1998. 
model arayışı başlar ve kabul edilen modelle yerel pratikler arasında bir zaman fasılası (temporal gap) varsayılır. ${ }^{7}$ Batı dışı modernite arayışlarında, entelektüeller de evrensellik iddiasındaki düşünsel ya da siyasî anlatılarla yerel gerçeklikleri bağdaştırma gündemiyle karşı karşıya kalırlar. Ve tüm bu modernleşme süreci reel siyasetin mecrasında, güvenlik, ticaret, kalkınma gibi farklı kaygıların baskısını hissederken deneyimlenir.

Partha Chatterjee'ye göre sömürgeciliğe bir tepki olarak neşet eden milliyetçi düşüncenin ilk aşamalarındaki en önemli gündem maddelerinden biri, "Doğu’nun ruhânî büyüklüğ̈ korunurken, Batı'nın sanayi ve teknolojilerinin öğrenilip taklit edildiği bir kültürel idealin", bir "kültürel sentez"in yaratılmasıdır. ${ }^{8} \mathrm{Bu}$ sentez arayışını kısmî adaptasyon olarak da adlandırabiliriz. Temel sorun Batı'nın kontrol girişimlerine karşı yerel kimliği güçlendirme gereğinin her durumda modernleşme çabası ile paralel gitmemesidir. Sentez, kısmî ya da bütünsel benimseme her durumda kimliğe karşı bir risk oluşturmaktadır. Chatterjee'nin ifadesiyle mesele, "başkasının kültüründe değerli olan bir şeyi, kendi kültürel kimliğini yitirmeden kabul etmek nasıl mümkün” olabilir sorusunda düğümlenmektedir. ${ }^{9}$

Adaptasyonun kısmî mi bütünsel mi olacağ1 sorusu, model arayı̧ı ve bu aray1şın gündeme getirdiği kopya (ve dolayısıyla tanım itibariyle ikinci dereceden) bir modernliğe mahkûm olma sorunları Türkiyeli entelektüelleri de 19. yüzyıldan beri meşgul etmektedir. ${ }^{10}$ Bir yandan Avrupa’nın bilgi kaynağı ve model olarak kaçınılmazlığı gündeme gelmekte, öte yandan küresel hiyerarşiler sahnesinde emperyalist planlarla yer alan Avrupa'nın model olarak uygunsuzluğu da vurgulanmaktadır. ${ }^{11}$ Avrupa'nın model alınmas1 gerektiği fikrini Avrupalıların Batı dışı coğrafyalara yönelik üstünlük iddialarından ve önyargılarından ayrıştırmak her zaman mümkün olmaz. Avrupa emperyalizmi 19. yüzyıl boyunca Osmanlı entelektüelleri için verili bir durumdur; üstelik I. Dünya Savaşı sonrası Osmanlı kentlerinde işgalci bir güce dönüşmüştür. Model olarak kabul edilen Batı'nın kısmen mi, bütün olarak mı benimseneceğine ilişkin son dönem Osmanlı İmparatorluğu'nda yapılan tartışmalar düşünce tarihi literatüründe yankı bulmuştur. Bunda Yusuf Akçura’nın

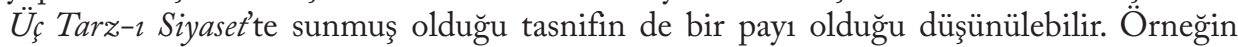
Niyazi Berkes, Türkiye'de Çăgdaşlaşma'da, manevî uygarlık-maddi uygarlık gibi ayrımlara başvurarak kısmî adaptasyondan yana tavır koyanları inceler. Namık Kemal'e göre Avrupa uygarlığının yararlı yanlarını, fenlerini ve endüstrilerini almak, kötü yanlarını ise almamak gerekmektedir. Berkes bu tavrın karşısında Batıcıları da çözümlemesine dâhil eder. Hüseyin Cahit ya da Tevfik Fikret gibi isimlere göre gereken bütünsel bir Batılılaşmadır ve muhafazakârların savunduğu Batı uygarlığının ancak "iyi” yanlarının alınması fikri örtülü bir Batı karşıtlı̆̆ından ibarettir. ${ }^{12}$

7 Dipesh Chakrabarty, Avrupa'yı Taşralaştırmak: Postkolonyal Düşünce ve Taribsel Farklılık, İstanbul, Boğaziçi Üniversitesi Yayınevi, 2012.

8 Partha Chatterjee, Milliyeţ̦i Düsünce ve Sömürge Dünyas, İstanbul, İletişim Yayınları, 1996, s.143.

9 Ibid, s.127.

10 Meltem Ahıska, Radyonun Sibirli Kapısı: Garbiyatçılık ve Politik Öznellik, İstanbul, Metis Yayınları, 2005.

11 Andrew Davison, "Ziya Gökalp and Provincializing Europe", Comparative Studies of South Asia, Africa and the Middle East, Cilt 24, No.3, 2006, s.377-390.

12 Niyazi Berkes, Türkiye’de Çă̆daşlaşma, Ankara, Bilgi Yayınevi, 1973, s.339. 
Osmanlı döneminde farklı perspektiflerin varlığına işaret eden Berkes, Cumhuriyet dönemini ele alırken hâkim görüşün bütünsel ve koşulsuz Batılılaşma olduğu sonucuna ulaşır. 1926'da kabul edilen Medeni Kanun'u değerlendirirken Berkes'in dönemin Adalet Bakanı Mahmut Esat'tan yaptığı alıntı, tek-parti döneminde koşulsuz Batılılaşmanın kabul edilmesinin ilanı gibidir:

Türk ulusunun çağdaş uygarlığı, onun yaşayan ilkelerini olduğu gibi kabul etme kararını verdiğini unutmamak gerekir. ...Çăğdaş uygarlığa katılma, onu benimseme yolunda kesin kararla yürüyen Türk ulusu, çağdaş uygarlığ1 kendine uydurma değil, her ne pahasına olursa olsun [kendini] o uygarlığın gereklerine uydurma zorunluluğundadır. ${ }^{13}$

Berkes bunun dışındaki farklı görüşleri ele almaz. Tarık Zafer Tunaya ise Türkiye’nin Siyasî Hayatında Batılılaşma Hareketleri adlı kitabında ilk olarak "Garpçılar”, İslâmcılar, Türkçüler, meslekçiler ve sosyalistler başlıkları altında 1908 sonrası dönemdeki farklı perspektifleri ele alır, fakat sonrasında, Berkes'ten farklı olarak, Cumhuriyet döneminde Batılılaşmaya ilişkin farklı yaklaşımları "bütüncüler” ve "kısmîci görüşler" başlıkları altında inceler. Tunaya'nın bu tasnifinin bu makaledeki tartışmaya en yakın yaklaşım olduğunu söylemek mümkün. Fakat Tunaya'nın analizi de iki nedenle tek-parti dönemi Kemalizm içi görüş ayrılıklarına ilişkin detaylı bir çerçeve sunmamaktadır. Birincisi, Tunaya'nın ana odağ1 1945 sonrası dönemdir. Kendi ifadesiyle Batılılaşmaya ilişkin söz ve yazı faaliyetleri 1945 sonrasında yoğunlaşmıştır. ${ }^{14}$ İkinci olarak, Tunaya’nın tasnifinin temeli Kemalizm içi tartışmaların detaylarını yansıtmaya elverişli değildir. Örneğin "bütüncüler" kısmındaki tartışmanın ana odaklarından biri 1953’te muhafazakâr düşünce insanları tarafından yayımlanmaya başlanan Türk Düşüncesi dergisidir. "Kısmîci görüşler” başlığg altında Kadro’nun tezi gelenekçi görüşlerle birlikte değerlendirilmektedir.

Bu makale ise münhasıran 1920'ler ve 1930'lara odaklanarak, Batı dışı bir toplumda modernleşme deneyiminin hangi temeller üzerine inşa edileceği sorusuna Kemalizm içinden verilen farklı yanıtları incelemektedir. Resmî söylemde modernleşmeyi Batılılaşma ile eşitleyen ve bütünsel Batılılaşma çağrısı yapan yaklaşımların, özgünlüğe işaret eden "biz bize benzeriz" vurgularıyla eşanlı olarak gözlenmesi, aslında yeknesak bir modernleşme tahayyülü olmadığına, farklı hatta birbirleriyle çelişen görüşleri de barındıran bir kuramsal tartışmanın varlığına işaret etmektedir. Bu çalışma, Kemalizm içinde iki farklı perspektifin temsilcileri olan, koşulsuz Batılılaşmadan yana tavır koyan Celâl Nuri ve özgün modernleşme projesinin gereğini savunan Şevket Süreyya'nın yazdıklarına odaklanarak bu tartışmayı incelemeyi hedeflemektedir. Makalenin temel iddialarından biri bu yazarların farklı modernite tahayyüllerinin ancak onların emperyalizm, küresel hiyerarşiler ve Avrupamerkezcilik karşısındaki konumlarının analiz edilmesiyle anlaşılabileceğidir. Bir başka deyişle, Kemalizm içi modernleşme ve Batı'yı model alıp almama tartışmaları, Kemalist entelektüellerin emperyalizm, küresel hiyerarşiler ve bu bağlamda Türkiye'nin ye-

13 Berkes, Ibid, s.470.

14 Tarık Zafer Tunaya, Türkiye'nin Siyasî Hayatında Batılılaşma Hareketleri, İstanbul, Yedigün Matbaas1, 1960, s.161-162. 
rine dair yaptıkları analizler ile Avrupamerkezcilik eleştirisinde hangi noktada durdukları çerçevesinde çözümlenebilir. Bu nedenle makalenin ikinci bölümü, Celâl Nuri ve Şevket Süreyya’nın küresel hiyerarşileri nasıl kavramsallaştırdıklarına odaklanmaktadır. Üçüncü bölümse, Celâl Nuri ve Şevket Süreyya’nın Avrupamerkezcilik karşısındaki tavırlarını analiz etmekte. Makalenin dördüncü bölümü, küresel hiyerarşiler ve Avrupamerkezcilik karşısındaki tavırların nasıl koşulsuz Batılılaşma ya da özgün modernleşme önerilerine öncülük ettiğini tartışmaktadır.

Son yıllarda giderek güçlenen eleştirel uluslararası ilişkiler incelemeleri dı̧̧ politika ile iç politika arasında varsayılan ayrımın yapay olduğunu ve bu ayrımın modern dönemin tarihselliği içinde belirli bir amaç doğrultusunda üretildiğini vurgulayarak siyasetin bütünsel görülmesi gerektiğini savunmaktadır. ${ }^{15}$ Bu makale 1920 'lerde ve 1930 'larda Kemalist entelektüellerin ülkeleri için geliştirdikleri modernleşme projelerini küresel güç dengesi ve Avrupa'nın iktisadi ve kültürel hegemonyasına dair analizlerinden hareketle formüle ettiklerini iddia ettiği ölçüde bu eleştirel yaklaşımlara eklemlenmekte ve genel bir yöntem olarak entelektüellerin tarihi yazılırken de iç politika ile dış politikanın ayrıştırılamayacak bir bütün olduğunu savunan görüşün akılda tutulmasını önermektedir.

\section{Kemalizm ve Küresel Hiyerarşileri Kavramsallaştırmak}

Kemalist tek-parti döneminde küresel hiyerarşilerin nasıl algılandığına ve kavramsallaştırıldığına bakıldığında, özellikle Türkiye'nin bağımsızlık savaşını bu çerçevede değerlendirmenin genel kabul gören ve Mustafa Kemal tarafindan da benimsenen bir tavır olduğu gözlenir. Mustafa Kemal, 1922'de İran Elçisini kabul ederken Türkiye'nin mücadelesinin "bütün mazlum milletlerin, bütün şarkın dâvası" olduğunu belirtir ${ }^{16}$ ve Şark milletlerinden dayanışma beklentisini dile getirir. Eylül 1923'deki bir demecinde ise küresel hiyerarşilerle Oryantalist önyargılar arasındaki bağa işaret ederek bir eleştiri geliştirir: "Avrupa'da hâlâ Türk'ün her türlü terakkiye hasım bir adam olduğu, mânen ve fikren inkişafa gayrı müsait bir adam olduğu zannedilmektedir." ${ }^{17}$ Mustafa Kemal'e göre verilen mücadele, "bizi mâdun olmağa mahkûm bir kavim olarak” tanıyan Avrupa’nın zihniyetine karşı verilmektedir. 1933’e gelindiğinde de Mustafa Kemal aynı perspektif içinden küresel hiyerarşileri değerlendirmeyi sürdürmekte ve "bütün mazlum Şark milletlerinin uyanış"ndan söz etmektedir. Atatürk’ün Osmanlı'ya yönelik eleştirisi de küresel hiyerarşiler bağlamında somutlaşır.

Mustafa Kemal'in pozisyonuna paralel olarak tek-parti döneminin pek çok entelektüeli de anti-emperyalist bir bakış açısını benimsemiştir. Tek-parti döneminde gerek lider,

15 Bu bağlamda kapsamlı bir değerlendirme için bkz, Ali Balcı, “Đış Politika': Yeni Bir Kavramsallaştırma Bağlamında Egemenlik Mitinin Bir Analizi”, Uluslararası İliş̧kiler, Cilt 7, No.28, Kış 2011, s.3-29.

16 Mustafa Kemal Atatürk, Atatürk’ün Söylev ve Demeçleri, Cilt 2, Ankara, Atatürk Kültür, Ankara, Dil ve Tarih Yüksek Kurumu, 1997, s.44.

17 Mustafa Kemal Atatürk, Atatürk’ün Söylev ve Demeçleri, Cilt 3, Ankara, Atatürk Kültür Dil ve Tarih Yüksek Kurumu, 1997, s.87. 
gerekse entelektüeller düzeyinde gözlenen anti-emperyalist tavrın İttihatçı emperyalizm karşıtllğının bir devamı olduğunu vurgulamak gerekiyor. İttihatçı dönemin meşhur fikir adamlarından biri olan Celâl Nuri'nin özellikle 1913'de yayımlanan İttihad-ı İslâm: İslâmın Mazisi, Hâli, İstikbali kitabı dönemin anti-emperyalist duruşu açısından önemli bir yere sahiptir. 19. yüzyılın ikinci yarısından itibaren Ortadoğu’da anti-emperyalist ve ön-milliyetçi tavrın pan-İslâmcilık olarak şekil bulduğ ${ }^{18}$ ve Osmanlı'da da Batılı güçlerin vesayetine karş1 tepkinin de ilk kez İslâm birliği fikri odağında formüle edildiği $1^{19}$ hatırda tutulduğunda, Celâl Nuri'nin kitabını daha geniş bir bağlama oturtmak mümkün olur. Kimilerince materyalist olmakla eleştirilmesine karşın, Celâl Nuri, Avrupalı büyük güçlerin dayattıkları izolasyona karşı Osmanlı toprakları dışında yaşayan Müslümanlarla dayanışma arayışı olarak İslâm birliğini savunmuştur. ${ }^{20}$ Celâl Nuri İttihad-ı İslâm'da hakiki medeniyetin insanllğın ahlaki arınmışlğ̆ olduğunu ve sınâi medeniyette ilerlemiş olmasına karşın hakiki medeniyet bağlamında Avrupa'ya medeni denemeyeceğini iddia ediyordu. ${ }^{21}$ Celâl Nuri, uluslararası güç dengesini Şark ile "emperyalist Garp" arasında bir gerilim olarak görmekteydi ve bu kapsamda "Avrupa'ya husûmet" beslenmesi gerektiğini iddia etmekten de geri durmuyordu. Bu duruma çare olarak önerisi, İslâm dünyasının kaderinin Osmanlı'nın emperyalizme direnişinden ayrı tutulmamasıdır. Bununla beraber Celâl Nuri İslâm birliği taraftarlığının dinî değil, siyasî olduğunu, İslâm dünyasının sorunlarına çarenin hürriyet ve terakki olduğunu da vurgular. Celâl Nuri'nin İttihatçı dönemdeki bu keskin anti-emperyalist tavrına karşılik, 1926'da yayımlanan Türk İnkılâbinda daha yumuşak ve merkezi önemde olmayan bir emperyalizm eleştirisi gözlenir. Her ne kadar kitap boyunca Şark ve Garp ikiliğine vurgu yapılsa da emperyalizm kitap boyunca yalnızca bir kez, kapitülasyonların Osmanlı'nın beka hassa ve kabiliyetine verdikleri zarar bağlamında geçer. ${ }^{22}$ Celâl Nuri neden 1910'lardaki anti-emperyalist söylemini tadil ederek 1920'lerde daha yumuşak bir söylemi tercih etmiştir? Gelecek bölüm bu soruya yanıt oluşturabilecek bir tartı̧ma sunmakta.

Celâl Nuri'nin Türk İnkılâbinda emperyalizm merkezi bir kavram olarak yer almazken, Şevket Süreyyanın Türkiye'nin küresel hiyerarşide tâbi konumda oluşu hakkında çok daha sistematik bir perspektif geliştirdiği gözlenmektedir. Henüz Kadro yayımlanmadan önce, Ocak 1931'de Türk Ocakları'nda verdiği “İnkılâp ve Kadro" başlıklı konferans Şevket Süreyya’nın Kemalizm’in ideoloğu olmayı hedeflediğini göstermekle kalmaz, aynı zamanda Kemalizm'den bir bütünsel ideoloji çıkartma uğraşında emperyalizm kavramına ve küresel hiyerarşilere ilişkin bir bilince merkezi önem atfettiğine işaret eder. Şevket Süreyya'nın ifadesiyle "Türkiye milli noktai nazardan tam ve beynelmilel noktai nazardan orijinal ve şamil bir inkılap içindedir." Şevket Süreyya için bu inkılabın özü,

18 Nikki Keddie, "Pan-Islam as Proto-Nationalism", The Journal of Modern History, Cilt 41, No.1,1969, s.17-28.

19 Şerif Mardin, The Genesis of Young Ottoman Thought: A Study in the Modernization of Turkish Political Ideas, Princeton, Princeton University Press, 1962, s.60.

20 Cemil Aydin, The Politics of Anti-Westernism in Asia: Visions of World Order in Pan-Islamic and Pan-Asian Thought, New York, Columbia University Press, 2007, s.93-104.

21 Ş. Tufan Buzpınar, “Celâl Nuri’nin Batılılaşma ve İslam Anlayışı Üzerine Notlar”, Muhafazakâr Düsünce, Cilt 4, No.16-17, 2008, s.213-230.

22 Celâl Nuri İleri, Türk İnkılâbı, İstanbul, Kaknüs Yayınları, 2000, s.56. 
küresel hiyerarşilere karşı çımış olmaktır: "Milli inkılabımız metropoller ve müstemlekeler arasındaki cihanşumul bir tezadın neticesidir." Sömürgecilik ve sömürgeciliğe karşı mücadeleye bu kadar merkezi önem atfeden Şevket Süreyya, model alma, özgün ya da kopya bir projeyi izleme, kısmî ya da bütünsel adaptasyon gibi küresel hiyerarşilerin dayattığı kuramsal soruların ilk aşamadan itibaren farkındadır. Bir millî kurtuluş hareketi olan inkılabın fikir sistemini oluşturmak da bu sorulara verilen yanıtlarla mümkün olacaktır. Şevket Süreyya’nın ifadesiyle,

Milli Kurtuluş hareketimizin nizamı inkılap nizamıdır. Bu nizama demokrasi diyenler vardır, ancak bu yanlıştır. Ama Türk inkılabı demokratik bir rejimi istihdaf eden bir inkılaptır denilebilir. Bu nizam liberalizm, parlamentarizmle tezat halindedir. Hülasa Türk inkılabı, gerek hareket noktaları, gerek seyrindeki istikamet itibariyle, mevcut hareketlerin hiçbirinin peyki ve kopyası olmayan müstakil bir harekettir. ${ }^{23}$

Dönemin resmi söyleminin de Kurtuluş Savaşı'nı anti-emperyalist bir mücadele olarak nitelendirdiği hatırlandığında Şevket Süreyya’nın "Millı̂ Kurtuluş Hareketi” kavramsallaştırmasının tamamen yeni olduğu söylenemez. Fakat Şevket Süreyya bu vurguyu resmi söylemin yapmadığı ölçüde kuvvetlendirmiş ve ileride gerçekleşecek olan millî kurtuluş hareketleri ile dayanışma boyutunu da eklemiştir. Kadro yayına başladığında da Şevket Süreyya siyaseti kavramsallaştırmasına esas oluşturan temel çelişkiyi sanayileşmiş ve sömürgeleri olan ülkeler ile sanayileşememiş ve sömürge olan ülkeler arasındaki zıtlık olarak belirler. ${ }^{24}$ Şevket Süreyya’ya göre Türk inkılabının gerçek anlamı, ancak bu sömürgecilik tezadı bağlamında yapılacak bir değerlendirilme ile mümkün olur. Şevket Süreyya’nın bakış açısı etkileyici şekilde sistematiktir. Günümüz sosyal bilimcileri de sonradan oluşacak kuramsal çerçevelerin izlerini bu sistematik yazıları okuduklarında tespit etmektedirler. Örneğin Ayşe Buğra-Trak’a göre, Şevket Süreyya’nın bazı argümanları iktisadi kalkınma literatürünün ana tezleri ile ciddi benzerlikler içermektedir. ${ }^{25}$ Haldun Gülalp "metropol ve sömürgelerin ilişkileri” ya da "dünya sistemi” gibi kavramların sıkça kullanıldığ Kadro’da ve Şevket Süreyya’nın yazılarında, erken bir Bağımlılık Kuramı görür. ${ }^{26}$ Eyüp ÖZveren'e göreyse Kadro ve Şevket Süreyya'da hem kalkınmacılı̆̆ı hem de Bağımlılık Ekolü'nü önceleyen unsurlar bulmak mümkündür. ${ }^{27}$ Özveren’in ifadesiyle, Kadro yazarları Büyük Buhran'da Türkiye'nin sanayileşmesi ve planlı ekonomiye geçiş için bir fırsat penceresi gördükleri ölçüde, Bağımlılık Kuramı'nın ana tezlerine, bu kuram ortaya çıkmadan çok önceleri yaklaşmı̧ olurlar.

23 Tekeli ve İlkin, Kadrocuları ve Kadro'yu Anlamak, s.131.

24 Şevket Süreyya, "Emperyalizm Şahlanıyor mu?”, Kadro, No.16, 1933, s.5-10; Şevket Süreyya, "Millî Kurtuluş Hareketleri Hakkında Bizim Tezimiz", Kadro, No.12, 1932, s.38-44.

25 Ayşe Buğra-Trak, "Development Literature and Writers from Underdeveloped Countries: The Case of Turkey", Current Anthropology, Cilt 26, No.1, 1985, s.89-102.

26 Haldun Gülalp, "Nationalism, Statism and the Turkish Revolution: An Early 'Dependency' Theory", Review of Middle Eastern Studies, No.4, 1985, s.69-85.

27 Eyüp Özveren, "The Intellectual Legacy of the Kadro Movement in Retrospect", METU Studies in Development, Cilt 23, No.4, 1996, s.565-576. 
Mustafa Kemal'in zımnî icazetiyle ${ }^{28}$ yayına başlayan dergide Kadro yazarları sıklıkla müstemleke tezadı, yarı-sömürgeler ve Avrupa'ya iktisadi bağımlılık konularını tartışmışlardır. Şevket Süreyya da derginin yayın hayatı boyunca bu bağlamdaki analizlerini derinleştirir ve özellikle 16. sayıda yayımlanan "Emperyalizm Şahlanıyor mu?” başlıklı makalesinde küresel hiyerarşilerin detaylı bir analizini sunar. Müstemlekeciliğin Sanayi Devrimi öncesi ve sonrası olmak üzere iki dönemi vardır. İlk dönem Keşifler Çağı ile başlar ve 18. yüzyılın sonuna kadar devam eder. Bu devrin ana özelliği yağma, fetih ve köleliğe dayalı olmasıdır. Şevket Süreyya'nın ifadesiyle daha sonraları Avrupa’nın iktisadi üstünlüğü ve kültürel hegemonyasını temin edecek olan sermaye birikimi bu ilk devirde vücut bulmuştur. Emperyalizmin cihanşümul bir düzen haline gelmesi ise Sanayi Devrimi ile mümkün olmuştur. Misyonerler, bezirgânlar ve kompradorlar bu yeni dönemin aktörleridir. İlk dönem emperyalizmin hedefi yeni keşfedilmiş kıtalarken, yeni emperyalizmin emtia dalgaları Uzak ve Yakın Doğu'nun sınırlarını da zorlamıştır. Emtia istilâsı yerel zanâati ve esnaf üreticiliğini köreltir. Küçük üretimin ölmesi bunun fabrika tipi üretimle ikame edilmesine de yol açamaz. Üretime dayanmayan bir ticaret yok olan yerel üretimin yerini alır. Şevket Süreyya'nın küresel hiyerarşilere ilişkin analizinde sömürgeciliğin Avrupa'nın kurucu bir unsuru olduğu oldukça net olarak belirtilmektedir: "Ĕğer müstemlekeler yağma edilmeseydi ve eğer makineler icat olunmasaydı bugünkü Avrupa vücut bulmazdı." ${ }^{29}$

Şevket Süreyya, yeryüzünde insanların müstemlekeci karargâh ve müstemleke karargâh olmak üzere iki büyük kampa bölündüğünü söylemekteydi. Emperyalizmin temel tanımı sermaye, sanayi ve müstemleke hâkimiyetini elinde tutan mahdut memleketlerin diğer memleketler üzerinde tesis ettikleri meydan okuma (teaddî) ve istismar düzenidir. Bu düzen kendi bilimini ve ideolojisini dahi kurmuştur. Şevket Süreyya 1930’larda her yönden esmekte olan ırkçı rüzgârlara karşın, ırklar arası hiyerarşi olduğuna ilişkin iddiaların bilimselliğine ikna olmaz: "Bir kısım milletlerin diğer kısım milletler elinde esir olmasının ve esir yaşamasının meşru sebepleri âdeta ilmen ispat edilmişti." ${ }^{30}$ Şevket Süreyya "bir buçuk milyarlık müstemleke ve yarı müstemleke halkının nihayet iki yüz elli milyonluk sanayici memleketler hesabına çalı̧masının insaniyet ve demokrasi prensiplerine gayet uygun olduğunda karar kılan ilmî hakikatlerin" de artık kimseyi tatmin etmediğini vurgular. Artık bu emperyalist düzene karşı “millı̂ kurtuluş nizamı” vardır. Şevket Süreyya'ya göre bir isyan niteliğinde olan bu sistem arayışı, müstemleke kayıtlarının tasfiyesi ve sanayinin bütün dünyaya yayılmasına dayanmaktadır.

Şevket Süreyya millî kurtuluş hareketinin temelinin millî bağımsızlık olduğunu belirtir. Ortak iyiyi temsil eden "millet"in istiklâli için, millî birliği zedeleyen "ferdiyetçi, zümrevî ve sınıfî" perspektiflere bu davada yer vermemek gerekmektedir. Şevket Süreyya'nın ifadesiyle millî kurtuluş hareketleri devri, toplumun "içtimaî inzibata" en çok ihtiyaç duyduğu bir geçiş sürecidir. Bu inzibatlık görevi, feragatlı ve disiplinli "avangard"lara, umumî menfaatleri müdafaa eden rehber kadroya düşmektedir. Şevket

28 Tekeli ve İlkin, Kadrocuları ve Kadro'yu Anlamak, s.142.

29 Şevket Süreyya, “Emperyalizm Şahlanıyor mu?”, Kadro, No.16, 1933, s.5-10.

30 Ibid, s.8. 
Süreyya'ya göre müstemleke tezadı pasifizm, siyasî idarei maslahatlar, sokak veya diplomasi nümayişleri ile çözülemez. Sömürge zıtlığının çözülmesi ancak bir bağımsızlık savaşı ile olabilir. Bu argüman çerçevesinde Şevket Süreyya ile sömürgecilikten çıkı̧ın ancak şiddet sayesinde olabileceğini savunan Fanon arasında da bir paralellikten söz edilebilir. Şevket Süreyya'ya göre, millî kurtuluş hareketleri bağımsız bir devlet sisteminin bütün ideolojik unsurlarını içerdiği için ve bir "yeniden doğuş ve kurtuluş" hadisesi olduğu ölçüde bir ink1lâptır. ${ }^{31}$ Şevket Süreyya ayrıca millî kurtuluş hareketlerine girmiş olan ya da namzet bulunan bütün memleketler arasında, "lisan, kan veya mahiyet fark" 1nı aşan bir mânevî kader birliği varsaymaktadır.

Önceki dönemde de emperyalizm önemli bir gündem maddesi oluşturmasına karşın, İttihatçı entelektüellerin emperyalizmin işleyişine ilişkin anlayışları sınırlıyd. ${ }^{32}$ Alexander Parvus'un İttihatçı çevrelerde ilk kez ekonomi politik temelli perspektifi yaygınlaştırması ve Osmanlı İmparatorluğg'nun konumunun bir yarı-sömürge olarak anlaşılması gereğinden söz etmesi ${ }^{33}$ de İttihatçı dönemdeki emperyalizme ilişkin kavrayışın sınırlarını çok değiştirmemiştir. İttihatçıların bu sınırlılıkları hatırlandığında Şevket Süreyya'nın sömürgecilik analizinin derinliği daha iyi anlaşılır. Elbette, Doğu Emekçileri Komünist Üniversitesi'nde (KUTV) almış olduğu eğitim, Moskova ve Bakü yıllarında uluslararas1 konjonktürü Sovyet penceresinden gözlemek ve Lenin'in emperyalizm üzerine tezleri hakkında düşünmüş olmak Şevket Süreyya'nın daha derinlikli bir analiz geliştirmesine katkıda bulunmuştur. Mustafa Türkeş'in ifadesiyle, Lenin'in perspektifinin etkisiyle başta Şevket Süreyya olmak üzere Kadro yazarları bütün sömürgelerin millî bağımsızlıklarına kavuşacakları ve bu süreçte kapitalist-emperyalist düzenin yıkılacağı öngörüsünde bulunmaktadırlar. ${ }^{34}$ Ayrıca Şevket Süreyya'nın Moskova yıllarında ana akım Sovyet perspektifinin dışında Sultan Galiyev'in görüşlerinden de etkilenmiş olma olasılığı kayda değerdir. Özellikle Galiyev'in temel çelişkiyi sınıf üzerinden tanımlamak yerine sömürgeciler ile "proleter milletler" arasında zitlı̆ga odaklanması Şevket Süreyya, Kadro yazarları ve Kemalizm'in genelinde gözlenen "mazlum milletler" söylemini öncelemektedir. ${ }^{35}$ Mustafa Türkeş Galiyev'in Kadro'ya doğrudan etkisinin izini sürmenin mümkün olmadığını belirtirken ${ }^{36}$, İlhan Tekeli ve Selim İlkin ise farklı koşullardan kaynaklanan görüş farkları olmasına karşın Galiyevcilik ile Şevket Süreyya ve Kadrocuların aynı temel kabullere sahip olduklarını vurguluyorlar. ${ }^{37} \mathrm{Bu}$ çerçevede Şevket Süreyya da sınıf çelişkisini değil, sömürgecilik tezadını siyasetin merkezine yerleştirir ve millî kurtuluş hareketlerini bu temel çelişkiye karşı çıma üzerinden tanımlar. Başka bir ifadeyle sınıf çelişkisinin siyasetin

31 Süreyya, Ibid.

32 Çağlar Keyder, State and Class in Turkey: A Study in Capitalist Development, Londra, Verso, 1987, s.53.

33 Asım Karaömerlioğlu, "Rusya, Almanya ve Türkiye'de Büyük Bir Kozmopolit Entelektüel ve Eylemci: Helphand-Parvus”, Doğu Batı, No.37, 2006, s.157-179.

34 Mustafa Türkeş, "The Ideology of the Kadro [Cadre] Movement: A Patriotic Leftist Movement in Turkey", Middle Eastern Studies, Cilt 34, No.4, 1998, s.105.

35 Buğra-Trak, "Development Literature and Writers"; Özveren, "The Intellectual Legacy".

36 Mustafa Türkeş, Kadro Hareketi: Uluş̧u Sol Bir Akım, Ankara, İmge Kitabevi, 1999, s.106-109.

37 Tekeli ve İlkin, Kadrocuları ve Kadro'yu Anlamak, s.533-540. 
merkezi çelişkisi olmadığı iddiası, Şevket Süreyya'yı küresel hiyerarşilere daha fazla odaklanmaya ve bu çerçeve içinde daha detaylı analizler yapmaya yöneltmiştir.

\section{Avrupamerkezcilik Karşında Kemalizm}

Makalenin giriş bölümünde, Batı dışı modernite deneyimlerinin önemli bir ortak özelliğinin model arayışı olduğu vurgulanmıştı. Küresel hiyerarşiler bağlamında gelişen bu arayışa model alınan ile takipçi konumda olan toplum arasında bir zaman fasılası olduğuna ilişkin bir gecikmişlik algısı da eşlik eder. Batı dışı modernite deneyimlerinin entelektüel öncüleri, kendi düşünsel çabalarını tam da bu bağlamda veriyorlardı. Model alma sorusuna kısmî adaptasyon ile koşulsuz/bütünsel adaptasyon seçenekleri de eşlik etmekteydi. Bu soruların karmaşıklığını Avrupamerkezciliğin iki anlamını hatırlayarak çözümlemek mümkündür. Avrupamerkezciliğin birinci anlamı Avrupa’nın üstünlük iddiasıyla ilişkilidir. İkinci anlamı ise daha çok bir metodoloji sorununa işaret eder ve Avrupa'nın ve/veya Batı'nın her şeyin üzerinde, kuramsal bir bilgi kaynağı olduğunu iddia eder. Avrupamerkezciliğin bu iddiaları ister istemez Avrupa'da vücut bulmuş olan perspektiflerin yerel gerçekliklerle nasıl bağdaştırılacağı sorusunu gündeme getirmektedir. Batı dışı modernite deneyimlerinde, Avrupamerkezci bir moderniteden yana olan entelektüeller, seçilen modeli yerel gerçeklerle bağdaştırma düşüncesini yanlış bularak koşulsuz bir benimsemeden yana tavır koyuyorlard1. Bunun karşısında, Avrupamerkezciliğe karşı olan entelektüeller yerel gerçekliği önemsiyorlar ve buna bağlı olarak ya tamamen özgün bir modernite arayışına giriyorlar ya da modelin çeşitli unsurlarının reddedilerek kısmen benimsenmesini savunuyorlardı. 1920'ler ve 1930'lar Türkiye'sinde bu iki pozisyon da gözlenmekteydi. Celâl Nuri, özellikle Türk İnkılâbı adlı kitabında Avrupamerkezciliği savunuyordu. Buna karşın, Şevket Süreyya Avrupamerkezciliğin sert bir eleştirisini geliştiriyordu.

Celâl Nuri Türk Inkılâbinda temel bir mesele olarak medeniyet bahsini ele alıyor ve bir yandan kaç medeniyet olduğu sorusunu sorarken, bir yandan da Türkiye'nin hangi medeniyete katılması gerektiğini tartışıyordu. Bu konuları ele alırken Celâl Nuri sürekli olarak Avrupa'nın her konuda rakiplerine olan üstünlüğünü vurgulamaktaydı. Celâl Nuri'ye göre Avrupa medeniyeti ilerleme ve hürriyet medeniyetiydi. ${ }^{38}$ Sıklıkla Avrupa medeniyetini diğer medeniyetler ile kıyaslıyor ve bu karşılaştırmalarda Oryantalist klişelere başvuruyordu. ${ }^{39}$ Örneğin kitabın “Medeniyet” başlıklı bölümünü üstün konumda olan Avrupa medeniyetinin dinamik, diğer medeniyetlerin ise statik olduğunu iddia ederek açıyordu. ${ }^{40}$ Celâl Nuri'nin ifadesiyle Avrupa medeniyetine mensup olan ya da ilhak eden her millet (kavim) ilerlemekteydi ve bu medeniyet dışında kalan her kavim yenilmekteydi. Celâl Nuri bu noktada, Avrupa dışında olan ama ona karşı yenilmemiş olan Türkiye’nin istisnai konumunu vurguluyordu.

38 İleri, Türk İnkılâbı, s.64 ve 75.

39 Bu klişeleri sıklıkla kullanması Gustave Le Bon ya da Ernest Renan gibi Oryantalistlerin Celâl Nuri üzerindeki etkilerini de göstermektedir.

İleri, Türk İnkılâbı, s.59. 
Celâl Nuri karşılaştırmalı analizine İslâm'ı da dahil eder ve İslâm'ı Doğu'nun dinamizmden uzaklı̆̆ının başlıca sorumlusu olarak görür. Celâl Nuri hakiki İslâm’ı suçlamaz. Ona göre gerçek İslâmiyet, inancı temel alan akîde gibi insanlar arası ilişkileri esas alan muâmelâtı da dinin içinde konumlandırmış ve içtihâdı bir görev olarak değerlendirmiştir. Fakat sonraları dinî önderler içtihâd gereğini ihmal etmişler ve Celâl Nuri'nin ${ }^{41}$ parlamento olarak nitelediği icma-i ümmet ilkesini de unutmuşlardır. Celâl Nuri önceliğin hayata mı, yoksa geleneğe mi verilmesi gerektiğini sorar ve önceliğin hayatta olduğunu ifade eder. "Dinde görenek Müslüman âleminin terakkîyâtı kabûlüne mani" ${ }^{42}$ olarak, İslâm toplumlarını statik bir hale sokmuştur. Din, toplumu ilerleme fikrinden uzaklaştırdığı ölçüde ahlâk alanında belirleyici olma konumunu da koruyamamıştır. Celâl Nuri'nin ifadesiyle bu uykudan ilk uyanan Müslüman millet Türkler olmuştur. ${ }^{43}$

Doğu'da din son derece kuvvetliyken, Celâl Nuri Batı'da durumun tersi olduğunu söyler. Bu nedenle, ona göre Avrupa medeniyetine "Hristiyan medeniyeti" demek yanlı̧̧ıtır. Celâl Nuri bir bakıma kavramın kendisini kullanmaksızın Avrupa’nın nasıl sekülerleş̧iğini anlatır. Hıristiyanlık, Avrupa'nın dinamizmi sayesinde statik halden sıyrılmıştır. İslâm dünyasında; siyaset, medeniyet, yaşayış, kıyafet din tarafından belirlenirken Avrupa'da belirleyici olan fennî düşünüş usûlüdür. Bu nedenle Batı'da fikir meseleleri bir pîre, mürşide ya da eski bir metne bırakılmaz. Celâl Nuri'ye göre asırlar boyunca Şark ile Garp arasındaki mesafe genişlemiş ve bu iki âlem birbirlerine yabancılaşmışlardır. Avrupa’nın ilerlemesinde her milletin gerek bilimsel, gerekse kültürel katkıları olmuştur. Bu nedenle artık bu ilerlemede millî bir renk görülmez: "O terakkîyât artık bütün beşeriyyatın malı olmuştur. ...Demek istiyoruz ki Garb’’n attığı adımlar yalnız kendisi için değil, bütün beşerriyet için atılmıştır." ${ }^{44}$ Böylelikle Celâl Nuri, Avrupa medeniyetine evrensellik atfeder ve onu mutlak bilgi kaynağı olarak konumlandırır. Nitekim Doğu’nun ilminin geçerliliği artık şüphelidir ve bu ilim bütün insanlığa genelleştirilebilir değildir. Celâl Nuri bu ilmi geliştirmeye çalışmak külfetinden de hiçbir sonuç çıkmayacağını düşünmektedir. ${ }^{45}$ Garp

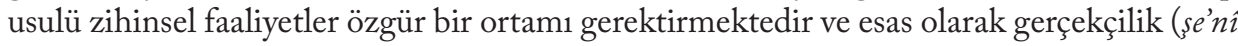
bir mantık) çerçevesinde şekillenir. Buna karşın Şark'ta düşünce özgür değildir ve sürekli olarak nakilci akıl yürütmelerden destek arar.

Doğu ile Batı arasındaki tüm bu Oryantalist karşılaştırmalardan sonra Celâl Nuri şu soruyu sorar: "Avrupa medeniyeti iyi midir, fena mıdır? Ona mensûb olmayanlar için kabûle değer mi, değmez mi?” ${ }^{46}$ Celâl Nuri'ye göre hiçbir medeniyet ibda olunamaz, yeni baştan yaratılamaz. Her medeniyet kendisinden önce gelen medeniyetlerin üzerine inşa edilir; dolayısıyla en salim medeniyeti ele almak mecburiyeti söz konusudur ve "o da, elhakk Avrupa'nınkidir". ${ }^{47}$ Bu nedenle, “Türklerin tuttukları yol doğrudur”. ${ }^{48}$ Celâl Nuri’ye

\footnotetext{
41 Ibid, s.63.

42 Ibid, s.65.

43 Ibid, s.66.

44 Ibid, s. 68 .

45 Ibid, s.69.

46 Ibid, s.73.

47 Ibid, s.77.

48 Ibid, s.78.
} 
göre Türk milletinin Garp medeniyetine girmesi, o medeniyeti de soyutlanmı̧̧ ve tekelci halden çıkarmaktadır. Türklerin Avrupa usûllerini benimsemeleri, Celâl Nuri'nin ifadesiyle, Avrupa'ya karşı Asya zaferinin de başlangıcı konumundadır.

Celâl Nuri 1926'da koşulsuz Batılllaşmayı savunarak Avrupamerkezci modernleşmeyi öne çıkartırken, 1930'ların başında Kadro’da Şevket Süreyya Avrupamerkezciliği, kavramın kullanımının en erken örneklerinden birini vererek, eleştiriyordu. Şevket Süreyya 1932'de "Europacentrisme'in Tasfiyesi" makalesini yayımladığında, kavramın europazentrish şekliyle ilk kullanımı olarak kabul edilen Alman jeopolitikçi Karl Haushofer'in Geopolitik des pazifischen Ozeans (1925) kitabının yayınlanmasının üzerinden sadece yedi y1l geçmişti ve Samir Amin'in Avrupamerkezcilik: Bir İdeolojinin Eleştirisi kitabının ${ }^{49}$ yayımlanmasına 50 yıldan daha fazla vardı. Şevket Süreyya'nın Avrupamerkezcilik tanımı şaşırtıcı biçimde Amin'in tanımıyla, ya da daha da genel olarak 1970'lerden itibaren dile getirilen Oryantalizm'e, Avrupamerkezciliğe ve Avrupa'nın kültürel hegemonyasına yönelik eleştirel perspektiflerle örtüşüyordu. Şevket Süreyya'nın Avrupamerkezcilik tanımı oldukça sade ve güçlüydü: "Europacentrisme, Avrupa tarihini cihan tarihinin merkezi telâkki etmek”tir. ${ }^{50}$ Şevket Süreyya Avrupamerkezciliğgi Batlamyus'un geocentrisme’ine benzetir. Geocentrisme ile dünya, "hakikatta, geniş kâinat sisteminin küçük ve tâbiy bir unsuru olduğu halde, bu sistemin merkezi ve mihveri gibi” sayılmıştı. Şevket Süreyya’ya göre Avrupamerkezcilik, "beşerin idraki üstünde hâlâ hakim olan” benzer bir algı hatasıdır. Bu hatanın tarihi Eski Yunan'a kadar geri gitmektedir: "Avrupa tarihi, hakikatta geniş cihan tarihinin küçük ve tâbiy bir unsuru olduğu halde, bu tarihin mihveri ve merkezi gibi sayılır. Bütün teharriler, bütün hükümler ve bütün hakikatlar, yalnız Avrupadan itibaren ve yalnız Avrupa içindir." ${ }^{51}$ Şevket Süreyya'ya göre Avrupamerkezcilik Avrupa haricindeki halkları Avrupa'ya tâbi saymakla insanlığın düşünce tarihinde olumsuz bir rol oynamıştır. Avrupamerkezcilik ile sömürgecilik arasındaki nedensellik ilişkisi açıktır. Avrupamerkezcilik vahşî bir hal aldıkça, sömürgecilik ve yağma Avrupa'nın "cihanşümul hegemonyası” için zemin hazırlar. Ticaret merkezlerinin değişmesiyle birlikte, "cihanın hayat kanalları, küçük Avrupa kıtacığı etrafında” birleşik bir sistem oluşturur.

Sömürgecilik ile olan ilişkisinin ötesinde Şevket Süreyya Avrupamerkezciliği tarih yönteminin bir hatası olarak da eleştirir. Avrupamerkezci tarihin ilk hatası, "ilk çağ", “orta çă̆", "yeniçağ” ve "son zamanlar” şeklindeki dönemlendirmedir. Bu dönemlendirme, medeniyeti Avrupa'ya özgü görür ve Avrupa dışındaki her türlü gelişmeyi “kaba” ve basit (mücerret) tecrübeler olarak niteler: "Bu destanda, Avrupa haricinde kalan veya Avrupaya karşı gelen her sima bir yıkı1cı ve bir barbar gibi tasvir olunur." ${ }^{52} \mathrm{Bu}$ tasnif gerek dünya medeniyetinin genel gelişmesini, gerekse Türk tarihinin karakteristik devirlerini yansıtamaz. Avrupamerkezci tarih “Türk tarihinin İlk çağı nerde başlar ve Orta çağı nerde biter?” sorusuna yanıt veremez; çünkü Avrupa tarihçisinin orta çağ olarak adlandırdığı dönemde Türk tarihi "rönesansını" çoktan bitirmiştir.

49 Samir Amin, Avrupamerkezcilik: Bir İdeolojinin Eleştirisi, İstanbul, Ayrıntı Yayınları, 1993.

50 Şevket Süreyya, "Europacentrisme’in Tasfiyesi”, Kadro, No.7, 1932, s.5-10.

$51{ }^{51}$ Ibid.

52 Ibid, s.7. 
Şevket Süreyya Kadro’nun 12. sayısında yayımlanan "Millî Kurtuluş Hareketleri Hakkında Bizim Tezimiz" başlıklı makalesinde Avrupamerkezcilik eleştirisini detaylandırır ve Avrupamerkezci modernleşme anlayışını reddeder. ${ }^{53}$ Karş1 çıktığ1 görüşü şöyle özetlemektedir: "Avrupa nizamı bu günün beşerî yahut üniversel nizamıdır. Onun iktisat, hukuk, siyaset, sanat, muaşeret ve saire bütün içtimâ̂ şekilleri bütün insaniyet için doğrudur ve makuldür. Başka memleketler için ilim ve hakikat denilen şey, Avrupanın bu içtimaî şekillerini tetkik etmekten ve benimsemekten başka ne olabilir?” Şevket Süreyya polemiğe yatkın üslubuyla bu görüşün savunucusu olarak Ağaoğlu Ahmed'i işaret eder; fakat bu çalışmanın çerçevesinde bu özetin Celâl Nuri'nin bakışını da yansıttığını ve belirli kişilerin görüşlerinden çok genel bir tavrı eleştirdiğini de hatırda tutmak gerek. Bu görüşe göre Avrupa’nın gelişme yolu, Avrupa haricindeki bütün cemiyetlerin tabiî gelişme yoludur ve "fertlerin çarpışması, firkaların çarpışması, sınıfların çarpışması, memleketin çarpışması, hulâsa klâsik demokrasinin bütün icapları" her toplumda Avrupa örneğinde olduğu gibi gelişmelidir.

Şevket Süreyya Avrupamerkezci modernleşme yaklaşımını reddederken, hem Avrupa'nın hem de kapitalizmin evrensellik iddialarının sorgulanması gerektiğini belirtir. Şevket Süreyya'ya göre kapitalizmin siyasî ve sosyal kurumları sadece Avrupa'ya özgün ve Avrupa'ya uygundur. Bu kurumlar sermaye ve sömürgecilik çelişkilerinden ayrı düşünülemezler. Kapitalizmin evrenselliğini sorgularken de Şevket Süreyya, kapitalizmin ticaret mekanizması bağlamında tüm dünyaya yayıldığını (cihanşümul) vurgulasa da, sınıf ilişkileri bağlamında tüm dünyaya yayılmadığını savunur. Kapitalizmin tüm dünyada geçerli olmasının önündeki en önemli engel sanayileşmenin eşitsiz coğrafi dağılımını gerektiren kendi iç mantığıdır: Kapitalizm bir kısım memleketlerin sanayisiz bırakılmasını gerektirir. Ayrıca Dünya Savaşı sonrasında Avrupa'daki işçi sınıfı da kapitalist sistemin sömürücü özelliklerine karşı çıkmıştır. Aynı karşı çıkış, dünya ölçeğinde isyan eden milletlerin müstemleke tezadına yönelik itirazlarında gözlenir. "Bir taraftan kapitalizmin cihanşümul hegemonyasına, diğer taraftan fikir ve ruh esaretine karşı duyulan tehevvür" (öfke) Şevket Süreyya'ya göre Türkiye'de bir cephe savaşı olarak tezahür etmiştir. Türkiye'nin İstiklâl Harbi, tüm sömürge ve yarı sömürgeler için güçlü bir örnek oluşturmaktadır. Ayşe Buğra-Trak bu argümanı yorumlarken, Kadro yazarlarının ekonominin sosyalin kontrolü dışına çıktığ 1 kapitalist sistemin doğal olmadığını vurguladıklarını belirtir. Buğra-Trak’a göre Kadro’da dile getirilen bu görüş, Karl Polanyi'nin Büyük Dönüşüm (1944) adlı kitabında geliştirdiği, kapitalizmin doğal olmadığ1 ve kapitalizme geçişle birlikte ekonomik alanın toplumsal alandan koptuğu perspektifiyle tamamen uyumludur.

Şevket Süreyya'nın Avrupamerkezcilik eleştirisi, tarih ötesinde sosyal bilimlerin geneline dair bir yöntemsel eleştiri de içerir. “İnkılâp Bitti mi?” başlıklı yazısında Avrupa iktisadını, Avrupa'nın fikir hemegonyasının bir uzantısı olarak görür ve bu disiplinin temel kabullerinin takip edilmemesi gerektiğini söyler. Şevket Süreyya’ya göre, kapitalizmin savunucuları müstemleke tezadının önemini görmezden gelmektedirler, çünkü aksi tavır

53 Şevket Süreyya, "Millî Kurtuluş Hareketleri Hakkında Bizim Tezimiz”, Kadro, No.12, 1932, s.38-44. 
Avrupa'nın iktisadi ve düşünsel hegemonyasını sarsacaktır. Şevket Süreyya'ya göre, sınıf çelişkisine müstemleke tezadından daha büyük önem atfedenler de hatalıdırlar. ${ }^{54} \mathrm{Bu}$ çerçevede, millî kurtuluş hareketlerinin entelektüel/öncü kadrolarına düşen görev topluma sömürgecilik tezadını anlatmaktır. Bu da ancak bu kadroların Avrupamerkezcilik karşısında eleştirel bir mesafe almalarıyla mümkün olur. Böylelikle Şevket Süreyya kendisine ve Kadro'ya biçmiş olduğu misyonu tarif eder: "Türkiyenin, yaşadığımız zamanın bu tarihî seyri içinde mevkıi, ne şu âlemin, o âleme hâs kaidelerine, ne bu âlemin o âleme elverişli kanunlarına uymadan, kendi bünyesinden gelen ve kendine uygun şartlara ve kanuniyetlere göre kendi yeni nizamını yapmasıdır." ${ }^{55}$ Şevket Süreyya' nın küresel hiyerarşilere ilişkin kavramsallaştırması, bu hiyerarşilerin başlıca kaynağı olarak kapitalizme işaret etmekte ve dolayısıyla bu hiyerarşilere meydan okumanın da ancak kapitalist olmayan bir toplumsal düzen tasarlamakla mümkün olabileceğine inanmaktadır.

\section{Kemalizm ve Modernite Tahayyülleri}

Celâl Nuri Türk İnkılâbi'nda kafasındaki modernite projesini serimlemeye 1926'ya kadar yapılan reformları değerlendirerek başlar ve atılan bütün adımların olumlu olduğunu vurgular. ${ }^{56}$ Celâl Nuri, Osmanlı dönemindeki yenileşme çabalarının taassuba karşı verilmiş efsanevi bir mücadele olduğunu belirtir. Fakat Osmanlı dönemindeki reform çabaları eski ile yeninin ikili bir şekilde yan yana yaşaması sonucunu doğurmuştur. Örneğin, eski medreselerle yeni mektepler yan yana yaşamışlar, ya da bir yandan Garp hukuku iktibas edilirken öte yandan fetvaların derlenmesi yoluna gidilmiş ve ortaya Mecelle-i Abkâm-ı Adliyye çıkmıştır. ${ }^{57}$ Bir diğer ifadeyle Osmanlı dönemi reformları koşulsuz Batılllaşmayı sağlayamamıştır. Cumhuriyet reformlarının esas başarısı, reform gündemini ikiliklerden kurtarmasıdır. Celâl Nuri ${ }^{58}$ yeni rejimin radikal reformculuğunu Türkiye'nin jeolojik olarak Asya'dan kopmasına ve Avrupaya kavuşmasına benzetir. Tarihte ilk kez vatanı "Garbî Asya olan bir millet o kıt'anın ictimaî ve tarihî mukadderatından" ayrılmaktadır. ${ }^{59}$ Türk milletinin Osmanlılıktan tecridi anlamına da gelen bu inkılâp, kısmî değil bütünseldir (küllî) ve Garp medeniyetine "bilâkayd u şart" iştirâk etme esasına dayanmaktadır. ${ }^{60}$ Celâl Nuri bu noktada Türk İnkılâbının en önemli olumlu özelliklerinden biri olarak özgün bir yönü bulunmamasını vurgular:

54 Şevket Süreyya'nın Avrupamerkezcilik eleştirisi Marksizmin Avrupamerkezciliğini de eleştirmektedir.Şevket Süreyya’ya göre Marksizm, sanayileşmiş Batı toplumları ile sanayileşememiş Asya toplumları arasındaki farkları analiz etmek için yetersiz kalmaktadır. Bkz. Şevket Süreyya, "Fikir Hareketleri Arasında Türk Nasyonalizmi II: Marksizm" Kadro, No.19, 1933, s.6-16, ayrica bkz. Türkeş, "The Ideology of the Kadro".

55 Şevket Süreyya, "İnkılâp Bitti mi?”, Kadro, No.3, 1932, s.5-10.

56 İleri, Türk İnkılâbı, s.111.

57 Ibid, s.113.

58 Ibid, s.83.

59 Ibid, s.115.

60 Ibid, s.84. 
Evet, bu inkılâb 'orijinal', Arapçası ibtidâî, hiçbir mahiyet arzetmemektedir. Yani Türkler bu hareketleriyle düşünüşte, yaşayışta, devlet, hükûmet ve maârif usûllerinde dünyaca bu zamana kadar mechûl ve yepyeni bir tarz ibda etmiş olmuyorlar. İnkılâb ittibâidir, yani biz bu hareketle mevcûd medeniyyetlerden birine, kendimizce en müsâid addettiğimiz tefekkür ve muâşeret, irfan ve idare usûllerine uyuyoruz. Üç yüz seneden beri bizi bağlayan ve şaşırtan Şarkî fikir ve idare tarzına veda ettik. Binâenaleyh vazifemiz iktibastan ibarettir. ${ }^{61}$

Türk İnkılâbı'nın görevlerini Avrupa'yı ittibâ etmek, yani ona uymak, onu izlemek ve Avrupa'dan iktibas etmek yani ondan aktarmak olarak tanımlayan Celâl Nuri'nin bakışı, Mahmut Esat'ın Medeni Kanun bağlamında dile getirdiği Batı medeniyetini koşulsuz kabul formülüyle örtüşür gözükmektedir.

Celâl Nuri Türk İnkılâbı'nın demokratik olduğunu ve "milletin mürşidi” olduğunu ifade eder. ${ }^{62}$ İnkılâp "avama düşünemediği bir yaşayış tarzın1... kabûl" ettirmektedir. Bu anlamda inkılâp temel özellik olarak özgürlüğü (serbestî) değil kabul ettirmeyi benimsemiştir. İnkılap koşulsuz özgürlüğe izin vermemekte ve köhne fikirler ile eski yaşayışı istememektedir. Celâl Nuri "Bugün halkımız yenilikleri memnuniyyetle telâkki ediyor. Acaba buna bâdi olan hükûmet kuvveti midir?" diye sorar. Verdiği yanıt "mutlak surette değil" olur. Yenileşmenin muhalifleri azınlıktadır ve fikirlerdeki ilerlemeler ile "prensip" sahibi bir hükûmetin kuvveti birleşince inkılâp meydana gelmiştir. İnkılâp çerçevesinde gerçekleşen "Garp medeniyetini” almaktır. Celâl Nuri'ye göre "bu, bir nokta-i nazardan Avrupa'nın zaferidir. Fakat diğer bir itibarla da Avrupalı olmayan veyahut öyle addedilmeyen bir milletin Avrupa üzerinde zaferi telâkki olunmalıdır." ${ }^{63}$

Celâl Nuri Türk İnkılâbı'nı değerlendirirken " $y ı k m a k$ da ehemmiyetli bir ameliye idi" der ve radikal (cezrî) hareket edildiğini kabul eder. Fakat "bundan sonra yapmak devri" gelmektedir. ${ }^{64}$ Koşulsuz Batılliaşmadan yana olan Celâl Nuri radikal dönüşümleri desteklemektedir. Fakat iki noktada tavrını devrimci bir dönüşüm ya da kopuştan değil, evrimden yana koyar. Celâl Nuri'ye göre, "Türk'ün dili ve dini artık takarrür etmiştir; bu iki sadedde ancak tekâmüle imkân var"dır. "İnkılâbımızı tekâmül takip etmek zarurîdir. Çünkü inkılâb maziyi yıkar, tekâmül ise istikbâli inşa eder." "65 Celâl Nuri Türk İnkılâbi'nı dil reformlarının arifesinde, henüz Latin Alfabesi’ne geçiş kararının alınmadığı bir ortamda kaleme alır. Kitabın odakları arasında dil ve "Elifba Meselesi" de yer almaktadır. Dilde aşırı sadeleştirmeye karşı çıkan Celâl Nuri, Arap alfabesini desteklemez. Fakat bir yandan da yeni bir alfabeye geçiş kararının uygulanabilirliğinden şüphe eder ve alınacak "fevri kararlardan" endişe ettiğini belirtir. ${ }^{66}$

61 Ibid, s.84.

62 Ibid, s.102.

63 Ibid, s.119.

64 Ibid, s.121.

65 Ibid, s.206.

66 Ibid. 
Celâl Nuri'ye benzer şekilde, Şevket Süreyya'nın kafasında da modernleşme siyasî ve toplumsal alanlarda kapsamlı bir dönüşüme denk düşmektedir. Modernleşme yeni bir siyasî rejim, yeni fikirler ve hatta "yeni insan" arayışıdır. ${ }^{67}$ Şevket Süreyya modernleşme modelini üç unsur üzerinden özetler: gerek iktisadi gerekse kültürel alanda devletçilik, liberal parlamenter demokrasinin reddi ve sömürgecilik karşıtllğ ${ }_{1}{ }^{68}$ Celâl Nuri'den farklı olarak Şevket Süreyya’nın modernite tahayyülü Türk milliyetçiliği ile şekil bulmaktadır. Milliyetçilik ile birleşen çoğulcu demokrasinin reddi, Şevket Süreyya'nın modernite tahayyülüne otoriteryen bir boyut ekler. Şevket Süreyya kafasındaki modeli serimlerken özellikle inkılâbın bitmemiş bir süreç olarak değerlendirilmesi gerektiğini vurgular. Önerdiği, Kemalist rejimin daha radikal ve kapsamlı bir reform programını benimsemesidir. Yeni kurulan nizam ileri tekniğe ve ileri cemiyet müesseslerine geçişe ilişkin sert bir mücadeleye dayanmaktadır. ${ }^{69}$ Bu noktada Şevket Süreyya Türk İnkılâbını 1789 ile de karşılaştııır. Fransız İhtilali bireyciliğin ve sokağın damgasını taşırken, bir harp sonu ihtilali olarak Türk İnkılâbında dönüşüme ilişkin duyulan heyecan kolektif bir ruh disiplinine dayanır. ${ }^{70}$ Şevket Süreyya'nın bireyciliğe karşı çekinceleriyle beraber okunması gereken bu değerlendirme, onun otoriteryen eğilimleri ile birlikte düşünülmelidir.

Şevket Süreyya Fransız Devrimi üzerine analizini detaylandırdığında, Fransız parlamentarizmini, esas olarak toplumun ortak iyisini temsil etmeyen milletvekillerinden müteşekkil olmakla eleştirir. Örneğin meclisteki din adamları ruhban sınıfının çıkarlarını temsil ederlerken, komünistler ihtilâlci proletaryayı temsil ederler. Bu nedenle Şevket Süreyya, Türk İnkılâbının Fransız devrimi ile hâkimiyeti milliye özünü paylaşmakla birlikte, bunun tecelli edeceği form konusunda ayrıştığını söyler. Demokratik sistem Türkiye'ye uymamaktadır. Gereken "Avrupaperest" şekilde kayıtsız şartsız siyasî sistem formunu almak değil, özgün bir model inşa etmektir. Bu özgün model arayışının ana unsuru herhangi bir sınıfın çıkarını öncelemeyen, ortak iyiyi hedefleyen bir devletçiliktir. Şevket Süreyya için devlet toplumdaki çıkar farklılıklarını aşabilecek bir mekanizma olarak düşünülmelidir. Fakat tam da Mustafa Türkeş’in vurguladığı üzere bunun nasıl gerçekleşeceği konusunda Şevket Süreyya ikna edici detaylar sunmaz. ${ }^{71}$

Şevket Süreyya ve Kadro yazarının modernite tahayyüllerinde toprak reformu, elektrikleştirme ve sanayileşme özel bir yere sahiptir. Şevket Süreyya sanayileşmenin gelecekte işçi sınıfının oluşmasına neden olabileceğini düşünür. Türk milletine düşen, nasıl geçmişe ait sorunlardan kurtulmuşsa, geleceğe dair sorunlardan da aynı şekilde korunmak ve kurtulmaktır. Geleceğe ilişkin başlıca sorun sınıfların "korkunç, kanlı ve amansız"

67 Şevket Süreyya, "Millî Kurtuluş Hareketleri Hakkında Bizim Tezimiz”, s.44.

68 Şevket Süreyya, "Sosyal Milliyetçiliğin Zaferi”, Kadro, No.35-36, 1934-1935, s.8-22.

69 Şevket Süreyya, "İnkilâp Heyecanı (Antuziasm)”, Kadro, No.2, 1932, s.5-8.

70 İlhan Tekeli ve Selim İlkin, Kadro'da yayımlanan bütün yazıları kapsayan niceliksel içerik analizlerinin sonucunda, dergide Fransız Devrimi'nin sürekli olarak olumsuz bir bağlamda kullanıldığını belirtiyorlar. Bkz. Tekeli ve İlkin, Kadrocuları ve Kadro'yu Anlamak, s.515.

71 M. Türkeş, "A Patriotic Leftist Development-Strategy Proposal in Turkey in the 1930s: the Case of the Kadro (Cadre) Movement", International Journal of Middle East Studies, Cilt 23, No.1, 2001, s.91-114. 
mücadeleleridir. ${ }^{72}$ Şevket Süreyya'nın çözüm önerisi fabrikaların devlet eliyle ve devlet mülkiyetinde kurulmasıdır.

\section{Genel Değerlendirme}

İlhan Tekeli ve Selim İlkin, Türkiye'nin yaşadığı modernite projesinde 1923-1950 dönemini "köktenci modernite projesi" olarak nitelerler. ${ }^{73}$ "Köktenci modernite projesi" gerek Osmanlı'nın sıkılgan ve dolayısıyla kısmî modernleşme çabalarından, gerekse Ziya Gökalp tarzı sentezci modernleşme arayışlarından farklıdır. ${ }^{74}$ Belirli ölçüde pozitivizmden beslenen köktenci modernleşme perspektifi, hukuk sisteminin düzenlenmesinden, mimarlık ve şehircilik faaliyetlerine kadar pek çok alanda etkisini göstermiştir. Bu makale tek-parti dönemi entelektüel tarihine odaklanarak, bu dönemde Kemalist çevreler içinde de farklı görüşler olduğunu, farklı entelektüellerin oldukça farklı hatta karşıt akıl yürütme ve önerilerle köktenci modernite projesini desteklediklerini ve yönlendirmeye çabaladıklarını gösteriyor. Makalenin temel iddialarından biri dönemin farklı modernite tahayyüllerinin, farklı yazarların küresel hiyerarşiler ve Avrupamerkezcilik karşısında benimsedikleri tavır ekseninde anlaşılabileceği. Bir yanda Celâl Nuri modernleşmenin ancak Avrupa'yı iktibas etme yoluyla başarılabileceğini savunurken, diğer yanda Şevket Süreyya tamamen özgün bir modelin gerekliliğini vurguluyor ve "Avrupamerkezciliğin tasfiye" edilmesi gerektiğini savunuyordu. Biri Avrupamerkezci bir modernleşme, diğeri özgün bir modernleşme önerisi getirmesine karşın, Celâl Nuri ve Şevket Süreyya tek-parti döneminin otoriteryen eğilimlerini desteklemekteydiler. Başka bir ifadeyle, benimsenmesi gereken ana modernleşme çerçevesine ilişkin zıt görüşlere sahip olsalar da Celâl Nuri ve Şevket Süreyya sadece köktenci modernite projesini desteklemekte değil, aynı zamanda onun otoriteryen boyutunu desteklemekte de bir görüş birliğine ulaşmaktaydılar. Celâl Nuri ve Şevket Süreyya Avrupamerkezcilik karşısında iki farklı Kemalist pozisyon geliştirmişlerdi. Makalenin kapsamına dâhil olmayan tek-parti rejiminin liderlerinin bu konudaki tavrıysa bu iki entelektüel duruşun ortasında konumlanmıştı.

Makalenin bir diğer temel iddiası Kemalist tek-parti döneminin entelektüel gündeminin Batı dışı bir modernite inşası olarak değerlendirilmesi ve benzer coğrafyalardaki deneyimlerle karşılaştırılmalı olarak ele alınması gerektiğiydi. Bu iddianın arkaplanında, Avrupa kapitalizminin genişlemesinin formel sömürgecilik, enformel sömürgecilik, bir ülkeyi himaye altına almak ya da nüfuz bölgeleri kurmak gibi farklı veçheleri tarafından kontrol edilmiş coğrafyaların modernite deneyimlerinde yüz yüze geldikleri yönündeki, kuramsal ve pratik sorunların ortak özelliklere sahip olduğu kabulü yer alıyor. İlhan Tekeli ve Selim İlkin de Batı'nın sınırında yer alan diğer coğrafyalarda Avrupa kaynaklı olan ve evrensellik iddiasında bulunan fikirlerin yerel gerçeklerle nasıl bağdaştırılmaya çalışıldığına ilişkin örneklerin Kadrocuların çabalarını çözümlerken önemli olduğunu vurgulu-

72 Şevket Süreyya, "Makinaların Muhacereti”, Kadro, No.23, 1933, s.6-11.

73 İlhan Tekeli ve Selim İlkin, Cumburiyetin Harcı, Cilt 1, Köktenci Modernitenin Doğuşu, İstanbul, İstanbul Bilgi Üniversitesi Yayınları, 2003.

74 İlhan Tekeli, Modernite Aşılırken Kent Planlaması, Ankara, İmge Kitabevi, 2001, s.65. 
yorlar. ${ }^{75}$ Tekeli ve İlkin, 1910'lar Romanya’sında Marksizm ve popülizmin geç sanayileşen ülkeler bağlamında nasıl algılandığının ya da 1930'lar Latin Amerika'sında milliyetçilikle sosyalizmi bağdaştırma çabalarının Kadro için uygun kıyaslama referansları olduğunu ifade ediyorlar. Bu makalede ise karşılaştırmalı analize Batı dışı deneyimlere eşlik eden model arayışları ve seçilen modellerin kısmen mi, yoksa koşulsuz ve bütünsel olarak mı izleneceğine dair tartışmaların da dâhil edilmesi gerektiği savunulmuştur. Farklı bağlamlarda küresel hiyerarşilere verilen tepkilerin farklı türde milliyetçilikler veya kültürel sentez arayışlarına yol açtığı ve "başkasının kültüründe değerli olan bir şeyi, kendi kültürel kimliğini yitirmeden kabul etmek nasıl mümkün” olabilir ${ }^{76}$ sorusunun farklı coğrafi bağlamlar için geçerli olduğu kadar Türkiye tarihi için de geçerli olduğunu akılda tutmak gerekmektedir. Makale genelinde Türkiye bağlamında tartışılan "Avrupa medeniyetin temsilcisi midir?" sorusuna verilen yanıtların, Oryantalist önyargılara verilen tepkilerin ve Avrupamerkezli tarihin Batı dışındaki tarihi anlamak için yetersizliğine yönelik itirazların Türkiye bağlamına özgü olmadığının altını çizmek gerekmektedir.

Bitirirken, Batı dışı modernite arayışlarının bir diğer ortak özelliği olarak, küresel hiyerarşilere verilen tepkilerin sıklıkla yerlicilik (nativism) ya da bölgecilik (provincialism) tavrına dönüşebildiğini de vurgulamak gerekir. Samir Amin bu tavrı emperyalist evrensellik vaazlarına karşı çıkarken kültürel “özgüllük”leri öne sürmek ve kültüralist bölgecilik yapmak olarak tanımlamaktadır. ${ }^{77}$ Yerlici tavırda sıklıkla gözlenen bir özellik, Batı ile Bat1-dışı kültürler arasında mutlak zıtlık olduğunu kabul etmektir. Yerlici tavır kimi zaman modernitenin genel bir reddine kadar varabilmektedir. Amin'e göre "çıkmaz bir yol” olan bu tavır yer yer Celâl Nuri ve Şevket Süreyya'da da gözlenmektedir.

Celâl Nuri'deki yerlicilik tavrını iki ayrı düzlemde tespit etmek gerekmekte. Birincisi, Osmanlı İmparatorluğu'nun son döneminde pek çok entelektüelde gözlenen daha genel bir yerlicilik tavrıdır. Celâl Nuri farklı çalışmalarında İslâm'a, demokrat olmak gibi

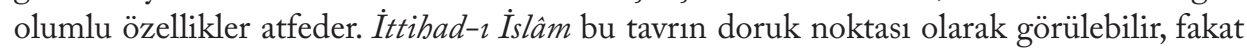
bu tavrın izlerine Türk Inkılâbinda da rastlanır. Kitabın geneline milliyetçi bir dil hâkim olmamasına karşın Anadolu'nun etnik homojenleştirilmesinden bahsederken yer yer yabancı düşmanı bir söylem benimsenmiştir. İkinci düzlemdeyse Celâl Nuri daha az rastlanan türde bir yerlicilik sergiler. Yerlicilik her zaman yerel kültürün üstünlük iddiası şeklinde tezahür etmez. Kimi zaman özcü bir tavırla, özcü bir ayrım geliştirerek Batı değerlerine mutlak üstünlük atfetmek de bir tür yerliciliktir. ${ }^{78}$ Türk Inkılâbinda geliştirilen yaklaşım bu tip yerliciliğin en iyi örneklerinden biridir. Celâl Nuri her bağlamda Batı medeniyetini mutlak bilgi kaynağı olarak kabul eder ve bu medeniyete üstünlük atfeder. "Garb Garb’tır, Şark ise Şark'tır” görüşünü benimseyen Celâl Nuri ${ }^{79}$ kitap boyunca Doğu ile Batı’yı özcü bir şekilde ayrıma tâbi tutarak yerliciğin özcülüğüne yakın düşer.

75 Tekeli ve İlkin, Kadrocuları ve Kadro'yu Anlamak, s.532-532.

76 Chatterjee, Milliyeţ̧i Düşünce ve Sömürge Dünyası, s.127.

77 Amin, Avrupamerkezcilik, s.131.

78 S. Farid Alatas, "On the Indigenization of Academic Discourse", Alternatives, No.18, 1993, s.307-338.

79 İleri, Türk İnkılâbı, s.172. 
Şevket Süreyya’nın yerliciliği ise Celâl Nuri'ye oranla çok daha belirgindir. Kadro döneminde Türk milliyetçiliğinin ve devletçiliğin kuramını yapmaya çalışan Şevket Süreyya, her türlü kozmopolizme karşı çıkmıştır. 1959'da yayımlanan Suyu Arayan Adam'da da aynı tavır devam eder. Şevket Süreyya'daki yerlici tavrı da üç düzlemde analiz etmek gerekmektedir. Şevket Süreyya’nın Kadro yazılarında vulgar bir milliyetçilik gözlenmese de tek-parti rejiminin milliyetçi tarih tezi yaratılması amacına destek vardır. Bu kapsamda Kadro sayfalarında Türk Tarih Tezi'nin bir parçası olarak Ergenekon Efsanesi'ni de selamlar ve yeni rejimin bu türden şiir ve ideale de ihtiyaç duyduğunu belirtir. ${ }^{80}$ Börtücene yahut Bozkurt'un “esir kavim”e çıkış yolunu göstererek kavmin kaderini değiştirdiği destan, şefin rehberliğinde nelerin başarılabileceğini göstermesi bakımından Türk inkılâbının sembolüdür.

İkinci olarak, Şevket Süreyya bütün yazılarında Türkiye'nin küresel hiyerarşilerdeki tâbi konumunu sorunsallaştırmıştır. Bu analizlerinde Şevket Süreyya ülkesini çatışma ve farklılıkların olmadığı birleşik bir birim olarak görür. Elbette emperyalizmin yerel işbirlikçileri vardır. Hatta Osmanlı döneminde işbirlikçiler yönetici konumundadırlar. $\mathrm{Bu}$ çerçevede Şevket Süreyya Türkiye toplumunun sınıfsız bir toplum olduğunu da iddia etmez. Tersine, örneğin toprak reformunun gerekçelerini sıralarken büyük toprak sahibi sınıfların, dolayısıyla sınıf çatışmasının varlığını vurgular. Fakat asıl odak sınıf çatı̧̧asından "müstemleke tezadı"na kaydıkça, analizlerinde Türkiye toplumunun farklılıkları ve çatışmaları görünmez olur. İlhan Tekeli ve Selim İlkin’e göre Kadrocular için “toplumun temsilinde millet temel ontolojik ünite haline gelmektedir." ${ }^{81} \mathrm{Bu}$ ontolojik birim çelişkileri yansıtmayan bir birimdir. Toplumdaki farklılıklar geri plana atıldıkça devlet çelişkilerden özerk, millî birliği sembolize eden bir varlık olarak kabul edilir. Şevket Süreyya müstemleke tezadını öne çıkardıkça, toplumun farklılıklarına ve devletin sınıflarla girdiği ilişkiye yeteri kadar dikkat etmemekle bir tür yerlicilik tuzağına düşmektedir.

Üçüncü olarak, Şevket Süreyya kuramsal derinlik bakımından sadece Celâl Nuri'den değil, muhtemelen dönemindeki tüm diğer entelektüellerden daha üst düzey bir konumdadır. Kuramsal çalışmanın çok da desteklenmediği bir ortamda kuramal meselelerle, bunların siyasetle bağlarını da kurarak ilgilenmiştir. Şevket Süreyya'nın en kayda değer kuramsal tartışmasının Avrupamerkezciliğin tasfiyesi hedefine yönelik çağrısı olduğunu söylemek mümkündür. Farklı boyutları ile Avrupamerkezciliği bir kavram olarak serimlemek dahi önemli bir katkıdır. Fakat Avrupamerkezcilik eleştirisiyle özgün modernite arayışı birleştiğinde, Şevket Süreyya sosyalizm ya da demokrasi gibi mevcut kavramları toptan reddetmeye girişir. Ona göre "bu hazır kelimeler birçoklarının idrakini bağlıyor ve hareket kabiliyetlerini kırıyor"dur. ${ }^{82}$ Bu reddiyeci tavrı ve bütünüyle farklı bir model yaratma arayı̧̧ını da bir tür yerlicilik olarak not etmek gerekir.

80 Şevket Süreyya, "Ergenekon Efsanesi”, Kadro, No.13, 1933, s.5-19.

81 Tekeli ve İlkin, Kadrocuları ve Kadro'yu Anlamak, s.503.

82 Şevket Süreyya, "Ergenekon Efsanesi". 


\section{Kaynakça}

Ahıska, Meltem. Radyonun Sibirli Kapısı: Garbiyatçılık ve Politik Öznellik, İstanbul, Metis Yayınlar1, 2005.

Alatas, Farid S. “On the Indigenization of Academic Discourse”, Alternatives, 1993.

Amin, Samir. Avrupamerkezcilik: Bir İdeolojinin Eleștirisi, İstanbul, Ayrıntı Yayınları, 1993.

Atatürk, M. Kemal. Atatürk’ün Söylev ve Demeçleri, Cilt 2, Atatürk Kültür, Ankara, Dil ve Tarih Yüksek Kurumu, 1997.

Atatürk, M. Kemal. Atatürk'ün Söylev ve Demeçleri, Cilt 3, Atatürk Kültür, Ankara, Dil ve Tarih Yüksek Kurumu, 1997.

Aydemir, Şevket Süreyya. Suyu Arayan Adam, İstanbul, Remzi Kitabevi, 1967. (birinci baskı, 1959)

Aydın, Cemil. The Politics of Anti-Westernism in Asia: Visions of World Order in Pan-Islamic and PanAsian Thought, New York, Columbia University Press, 2007.

Balıı, Ali. “Đı⿻̧ Politika': Yeni Bir Kavramsallaştırma Bağlamında Egemenlik Mitinin Analizi”, Uluslararası İlişkiler, Cilt 7, No 28, 2011.

Berkes, Niyazi. Türkiye’de Çă̆daşlaşma, Ankara, Bilgi Yayınevi, 1973.

Buğra-Trak, Ayşe. "Development Literature and Writers from Underdeveloped Countries: the Case of Turkey”, Current Anthropology, Cilt 26, No 1,1985.

Buzpınar, S. Tufan. “Celal Nuri'nin Batılılaşma ve İslam Anlayışı Üzerine Notlar, Muhafazakâr Düşünce, Cilt 4, No 16-17, 2008.

Chakrabarty, Dipesh. Avrupa'yı Taşralaştırmak: Postkolonyal Düşünce ve Taribsel Farklılık, İstanbul, Boğaziçi Üniversitesi Yayınevi, 2012.

Chatterjee, Partha. Milliyetçi Düşünce ve Sömürge Dünyası, İstanbul, İletişim Yayınları, 1996.

Çınar, Metin. Anadoluculuk ve Tek Parti CHP'de Sağ Kanat, İstanbul, İletişim Yayınları, 2013.

Davison, Andrew. "Ziya Gökalp and Provincializing Europe", Comparative Studies of South Asia, Africa and the Middle East, Cilt 24, No 3, 2006.

Demirel, Tanel. "Cumhuriyet Döneminde Alternatif Batılılaşma Arayışları: 1945 Sonrası Muhafazakâr Modernleşmeci Eğilimler Üzerine Bazı Değinmeler”, Uygur Kocabaşoğlu (der.), Modern Türkiye'de Siyasî Düsünce: Batıcılık, Cilt 3, İstanbul, İletişim Yayınları, 2002.

Gülalp, Haldun. "Nationalism, Statism and the Turkish Revolution: An Early 'Dependency' Theory”, Review of Middle Eastern Studies, No 4, 1985.

İleri, Celâl Nuri. Türk İnkılâbı, İstanbul, Kaknüs Yayınları, 2000.

İrem, Nazım. "Muhafazakâr Modernlik, 'Diğer Batı’ ve Türkiye'de Bergsonculuk”, Toplum ve Bilim, No 82, 1999.

İrem, Nazım. “Bir Değişim Siyaseti Olarak Türkiye'de Cumhuriyetçi Muhafazakârlık: Temel Kavramlar Üzerine Bir Değerlendirme”, Ahmet Çiğdem (der.), Modern Türkiye'de Siyasî Düşünce: Muhafazakârlık, Cilt 5, İstanbul, İletişim Yayınları, İstanbul, 2003.

Jusdanis, Gregory. Gecikmiş Modernlik ve Estetik Kültür: Milli Edebiyatın İcat Edilişi, İstanbul, Metis Yayınlar1, 1998. 
Karaömerlioğlu, Asım. "Rusya, Almanya ve Türkiye'de Büyük Bir Kozmopolit Entelektüel ve Eylemci: Helphand-Parvus”, Doğu Batı, No 37, 2006.

Keddie, Nikki. "Pan-Islam as Proto-Nationalism", The Journal of Modern History, Cilt 41, No 1, 1969.

Keyder, Çağlar. State and Class in Turkey: A Study in Capitalist Development, Londra, Verso, 1987.

Koçak, Cemil. Türkiye'de Millî Şef Dönemi (1938-1945), Cilt 1, İstanbul, İletişim Yayınları, 1996.

Mardin, Şerif. The Genesis of Younfg Ottoman Thought: A Study in the Modernization of Turkish Political Ideas, Princeton, Princeton University Press, 1962.

Özveren, Eyüp. “The Intellectual Legacy of the Kadro Movement in Retrospect”, METU Studies in Development, Cilt 23, No 4, 1996.

Şevket Süreyya. "İnkilâp Heyecanı (Antuziasm)”, Kadro, No 2, 1932.

Şevket Süreyya. “İnkılâp Bitti mi?”, Kadro, No 3, 1932.

Şevket Süreyya. “Europacentrisme'in Tasfiyesi”, Kadro, No 7,1932.

Şevket Süreyya. "Millî Kurtuluş Hareketlerinin Ana Prensipleri”, Kadro, No 8, 1932.

Şevket Süreyya. "Millî Kurtuluş Hareketleri Hakkında Bizim Tezimiz”, Kadro, No 12, 1933.

Şevket Süreyya. "Ergenekon Efsanesi”, Kadro, No 13, 1933.

Şevket Süreyya. "Emperyalizm Şahlanıyor mu?”, Kadro, No 16, 1933.

Şevket Süreyya. “Fikir Hareketleri Arasında Türk Nasyonalizmi, II: Marksizm”, Kadro, No 19, 1933.

Şevket Süreyya. "Makinaların Muhacereti”, Kadro, No 23, 1933.

Şevket Süreyya. “Sosyal Milliyetçiliğin Zaferi”, Kadro, No 35-36, 1934-1935.

Tekeli, İlhan. Modernite Aşıllırken Kent Planlaması, Ankara, İmge Kitabevi, 2001.

Tekeli, İlhan ve Selim İlkin. Uygulamaya Geçerken Türkiyede Devletçiliğin Oluşumu, Ankara, Orta Doğu Teknik Üniversitesi, 1982.

Tekeli, İlhan ve Selim İlkin. Bir Cumburiyet Öyküsü: Kadrocuları ve Kadro'yu Anlamak, İstanbul, Tarih Vakfi Yurt Yayınları, 2003.

Tekeli, İlhan ve Selim İlkin. Cumburiyetin Harcı, Cilt 1, Köktenci Modernitenin Doğuşu, İstanbul, İstanbul Bilgi Üniversitesi Yayınları, 2003.

Tunaya, Tarık Zafer. Türkiyenin Siyasî Hayatında Batılllaşma Hareketleri, İstanbul, Yedigün Matbaas1, 1960.

Turan, Ömer. “Oryantalizm, sömürgecilik eleştirisi ve Ahmed Rıza: Batı’nın Doğu Politikasının Ablâken Iflasinı yeniden okumak”, Toplum ve Bilim, No 115, 2009.

Türkeş, Mustafa. "The Ideology of the Kadro [Cadre] Movement: A Patriotic Leftist Movement in Turkey”, Middle Eastern Studies, Cilt 34, No 4, 1998.

Türkeş, Mustafa. Kadro Hareketi: Uluş̧u Sol Bir Akım, Ankara, İmge Kitabevi, 1999.

Türkeş, Mustafa. "A Patriotic Leftist Development-Strategy Proposal in Turkey in the 1930s: the Case of the Kadro (Cadre) Movement", International Journal of Middle East Studies, Cilt 33, No 1, 2001. 


\section{Summary}

The literature on Turkish intellectual history has now reached a certain degree of sophistication in terms of including details from different periods. Yet, this literature has not been careful enough to delineate intellectual debates of the single-party era. With a certain reductionism, the debates of the era have been studied by privileging disputes on economic policies. This article, however, goes beyond Mustafa Kemal-centered intellectual history of the single-party era and discusses different imaginations of modernity in the works of Kemalist intellectuals. The primary materials discussed in the article are Celâl Nuri's Turkish Revolution (1926) and Şevket Süreyya's Kadro articles from the 1930s. The article argues that the theoretical questions encountered by Kemalist intellectuals, such as appropriating a model for modernization or building an authentic modernity, partial or comprehensive adaptation of the model, were similar to the questions observed in other cases of non-Western modernities.

The second section of the article describes how Kemalist intellectuals conceptualized the global hierarchies. The third section deals with Celâl Nuri and Şevket Süreyya's position vis-à-vis Eurocentrism. Celâl Nuri accepted Europe as the only ultimate source of knowledge and hence follows a Eurocentric path, whereas, Şevket Süreyya criticized Eurocentrism by giving one of the earliest examples of the use of the term as such. Şevket Süreyya's definition of Europacentrism was quite simple and apt: "considering European history as the center of world history." Eurocentrism is a perceptual mistake that continues to dominate, according to Şevket Süreyya, human perception. He argued that Eurocentrism had had a negative impact on human history as it assumed that nonEuropeans were to be subjugated to Europe. He established a strong causal link between Eurocentrism and colonialism. Colonialism made the ground ready for Europe's worldwide hegemony.

The fourth section compares Celâl Nuri and Şevket Süreyya's imaginations of modernity. For Celâl Nuri, the program of Turkish revolution was about an unconditional adoption of Western civilization, and, he maintained that the revolution did not have anything original. Şevket Süreyya, however, conceptualizes the revolution as a national liberation movement, within the global colonial conflict. Accordingly, for Şevket Süreyya, the first and foremost duty of the Turkish modernity should be criticizing adorers of Europe and their understanding of democracy. He was utterly for a political model unique to Turkey.

The concluding section states that Kemalist intellectuals' argumentations were diverse in their support for the radical modernization project of the Republic. Moreover it argues that this diversity needs to be understood in relation to different positions with respect to Eurocentrism. The last section also incorporates the issue of nativism into overall discussion and argues that the Eurocentric model advocated in Turkish Revolution was a good example of a particular nativism, as long as it perpetuates the superiority of Western civilization. Şevket Süreyya's nativism was sometimes based on a nationalist discourse. He 
had the tendency to ignore the differences and conflicts within the local society by overemphasizing the colonial conflict, and he extended his criticism for Eurocentrism to reject the existing conceptual framework, such as democracy or socialism, by arguing that these were barriers to developing original ideas. 